\title{
Efektifitas Son-Rise Program dalam Meningkatkan Keterampilan Bahasa, Sosial Komunikasi pada Anak Autis
}

\author{
Asep Supena ${ }^{1}$, Nuryanti ${ }^{\bowtie}$, Karnadi $^{3}$ \\ Pendidikan Anak Usia Dini, Universitas Negeri Jakarta, Indonesia \\ DOI: $\underline{10.31004 / \text { obsesi.v6i4.964 }}$
}

\begin{abstract}
Abstrak
Anak autis memiliki kesulitan dalam membangun interaksi dan mempertahankan interaksi dengan orang lain seperti kontak mata dan atensi. Mengupayakan perkembangan keterampilan bahasa dan sosial anak autis sangat penting untuk memberikan makna pada setiap keinginan dan kebutuhan yang dimiliki oleh anak tersebut dengan cara humanis, sehingga kegiatan menyenangkan saat dilakukan. Metode penelitian ini adalah eksperimen dengan subjek tunggal yaitu anak perempuan usia 4 tahun 7 bulan yang didiagnosis sebagai penyandang ASD dan kegiatan dilakukan 20 sesi pertemuan. Pengumpulan data dilakukan melalui pengamatan langsung dan wawancara semi terstruktur dengan orang tua . Melalui analisis statistik deskriptif, hasil penelitian menunjukkan ada peningkatan kemampuan bahasa dan sosial komunikasi pada anak autis, tampak anak memiliki kesadaran lingkungan lebih baik, memiliki inisiatif membangun interaksi dengan lingkungan, lebih aktif dan partisipatif dalam pembelajaran serta menunjukkan keceriaan dalam setiap kegiatan. Hanya saja keterbatasan dalam penelitian ini adalah keterlibatan orang tua untuk melanjutkan kegiatan di rumah belum konsisten.
\end{abstract}

Kata kunci: Autis; Bahasa; Sosial Komunikasi; Son-Rise

\begin{abstract}
Autistic children have difficulty building interactions and maintaining interactions with others such as eye contact and attention. striving for the development of language and social skills for children with autism is very important to give meaning to each child's wants and needs in a humane way, so that activities are fun to do. This research method was an experiment with a single subject, namely a girl aged 4 years 7 months who was diagnosed with autistic and the activity was carried out in 20 meeting sessions. Data collection was carried out through direct observation and semi-structured interviews with parents. Through descriptive statistical analysis, the results showed that there was an increase in language and social communication skills in children with autism, it seemed that children had better environmental awareness, had the initiative to build interactions with childrenenvironment, more active and participatory in learning and showing joy in every activity. Limitation in this study is that the involvement of parents to continue activities at home is not consistent.
\end{abstract}

Keywords: Autistic; Language; Social Communication; Son-Rise

Copyright (c) 2022 Asep Supena, et al.

$\triangle$ Corresponding author :

Email Address : nurmak4k@gmail.com (Jakarta, Indonesia)

Received 14 December 2020, Accepted 10 January 2021, Published 31 January 2022 


\section{PENDAHULUAN}

Gejala-gejala ASD biasanya muncul sebelum anak mencapai usia 3 tahun dan pada sebagian anak gejalanya sudah ada sejak lahir. Sebagian kecil penyandang autis sempat berkembang normal, namun sebelum usia 3 tahun perkembangan menjadi terhenti, kemudian timbul kemunduran dan tampak gejala autism. Autisme sebagai gangguan perkembangan perpasif yang menghambat fungsi anak dalam 3 bidang, yaitu interaksi: sosial, komunikasi, dan minat yang terbatas (restriktif) dan perilaku berulang (repetitif).

Menurut Smily Jesu Priya Victor Paulraj, Noor Asyikin Bt Alwi, Jayachandran Vetrayan (2016), Autisme didefinisikan sebagai kelompok anak-anak khusus yang ditandai oleh kurangnya interaksi sosial, komunikasi verbal dan non-verbal, sensitif terhadap perubahan/rigid, memiliki perilaku berulang dan stereotype. Seringkali autistik dikaitkan dengan permasalahan sensori, regulasi emosional, perencanaan motorik, modulasi, dan organisasi perilaku. Anak ASD akan memiliki permasalahan dengan rutinitas yang berulang dan kaku, dan juga akan memiliki permasalahan dengan konsistensi perilaku yang diharapkan jika dengan perubahan situasi dan kondisi.

Keterlambatan berbicara biasanya dipengaruhi beberapa faktor, antara lain; Kurangnya stimulasi yang diterima anak pada usia dini, anak cenderung diam, tenang dengan permainan satu arahnya atau senang menonton TV. Anak juga bingung terhadap bahasa yang didengar atau diterima anak. Anak sering menonton TV dalam bahasa asing tetapi tidak pernah ada pendampingan untuk memahami bahasa tersebut. Atau sering kali orang tua memperkenalkan bahasa kedua disaat kemampuan berbahasa dasarnya (bahasaibu) belum matang dan pengolahan bahasaanak kurang optimal. Yang lainnya juga dapat mempengaruhi yaitu ada hambatan fungsi oral motor atau organ bicara sehingga anak tidak mampu berujar dengan artikulasi yang optimal. Hambatan persepsi dan menerima informasi bahasa diarea otaknya sehingga anak kesulitan untuk belajar mengenal bahasa. Biasanya anak dengan diagnosa khusus yang sering kali memicu hal ini terjadi, misalnya anak dengan autism, down syndrome, cerebral palsy.

Pengembangan bahasa pada anak ASD juga dapat menggunakan pendekatan humanistik, salah satunya adalah melalui pendekatan SRP dan pendekatan Hanen. SRP yang dikembangkan oleh suami istri Barry dan Sam Kaufman. Program ini pertama kali digunakan untuk membantu perkembangan anak lelakinya yang berumur 18 bulan, yang didiagnosis autis bernama Raun. Kemajuan yang dicapai oleh anaknya tersebut ditulis dalam buku SonRise Program (SRP) dan A Miracle to Believe In" (Endang, 2009). Optimalisasi pendekatan SRP ini dilakukan di rumah oleh orang tua dan keluarga, dengan beragam usia anak mulai usia dini hingga remaja akhir. Beberapa penelitian yang sudah dilakukan mengenai implementasi SRP, antara lain; Tahun 2016, United State of America yaitu penelitian tentang evaluasi pelatihan SRP untuk orang tua, yang akan diimplementasikan di rumah dengan variable usia anak awal (4-8) dan akhir (9-12). Penelitian lainnya tahun 2018, Bandung Indonesia mengenai SRP yang dilakukan orang tua untuk mengurangi perilaku task-off pada anak autis usia 6 dan 8 tahun. Penelitian tentang upaya guru meningkatkan kemampuan komunikasi anak autis melalui SRP bermedia interactive storybook berbasis CAI pada usia sekolah dasar dilakukan tahun 2018, Surabaya Indonesia. Menurut Sri dan Prima (2020), ada berbagai metode dalam mengembangkan bahasa ekspresif diantaraya metode bercerita dan bermain peran, metode bercerita menggunakan media boneka tangan Mucca mampu meningkatkan kemampuan bahasa ekspresif anak.

Dalam Son-Rise Program (SRP) peran lingkungan dalam perhatian dan keterlibatan bersama dianggap sebagai keterampilan yang sangat penting yang dapat mendorong interaksi sosial dan mendorong perkembangan bahasa anak yang lebih baik. Membangun interaksi, fokusnya adalah interaksi dengan anak, dan memotivasi anak untuk mau membangun interkasi dengan fasilitator. Ruang bermain menjadi tempat fasilitator membangun interaksi dalam permainan dengan anak dan meminimalkan masalah perilaku pada anak. Mengembangkan fleksibilitas dan waktu yang efektif; dalam SRP hampir tidak ada 
waktu yang sia-sia, anak tidak dibiarkan sendiri saat fasilitator atau terapis menyiapkan kegiatan tetapi dalam SRP anak akan bermain bersama fasilitator dengan waktu yang tersedia sepenuhnya.

Susan Davis (2002) mengatakan, motivasi adalah masalah utama pada anak ASD, mereka sering tampak tidak tertarik untuk mempelajari apa yang ditawarkan oleh fasilotator lebih tertarik melakukan perilaku berulang yang dapat menstimulasi dirinya sendiri atau "ism". SRP menggunakan prinsip "3Es" antara lain; Energy (Energi/semangat), Excitement (Kegembiraan), Enthusiasm (Atusias). Dalam SRP menyebutkan bahwa ism sangat penting bagi anak karena menenangkan anak, pandangan tentang perilaku yang merangsang atau menstimulasi diri sendiri atau ism, fasilitator Son-Rise mencoba untuk tidak menghentikan secara paksa, melainkan mereka bergabung atau "joining" dengan anak dalam perilaku berulang mereka yang menstimulasi diri sendiri atau ism, hal ini dilakukan sebagai kesempatan untuk menciptakan hubungan antara fasilitator dan anak.

Metode ini yang membuat SRP begitu unik dengan pendekatan yang berbeda. Menurut Ria, Sri dan Asep (2020) menyatakan bahwa bermain merupakan wadah untuk anak bersosialisasi dengan lingkungan sekitar, menjadi cara yang tepat untuk menumbuhkan rasa percaya diri dan rasa ingin tahu yang kuat, dengan bermain pula anak dapat melakukan aktivitas lain yang bisa mengembangkan jiwa sosial anak, komunikasi anak serta menghargai teman sebaya atau orang lain, serta dapat mengasah potensi yang dimiliki anak, maka dengan demikian bermain merupakan salah satu pilihan yang tepat untuk memupuk rasa percaya diri anak. Adapun manfaat bermain adalah bermain menurut Wulan (2015) meliputi seluruh aspek perkembangan anak antara lain: (a) perkembangan bahasa, (b) perkembangan moral, (c) perkembangan social, (d) perkembangan emosi, (e) perkembangan kognitif, (f) perkembangan fisik, (g) perkembangan kreativitas.

Menurut Astri, Rien dan Karnadi (2020) melalui aktivitas bermain, seorang anak dapat memperoleh banyak informasi dan pengetahuan tentang lingkungannya. Selanjutnya, mereka dapat menggunakannya pada saat menghadapi kendala dalam kelompok bermain. Berikutnya adalah aspek keluwesan berpikir (flexibility), yaitu kemampuan untuk memproduksi sejumlah ide, jawaban-jawaban atau pertanyaan-pertanyaan yang bervariasi, dapat melihat suatu masalah dari sudut pandang yang berbeda - beda, mencari alternatif atau arah yang berbeda-beda, serta mampu menggunakan bermacam-macam pendekatan atau cara vmibm pemikiran. Orang yang kreatif adalah orang yang luwes dalam berpikir. Mereka dengan mudah dapat meninggalkan cara berpikir lama dan menggantikannya dengan cara berpikir yang baru. Fleksibilitas mengarah ke beragam ide-ide yang menggunakan berbagai kategori konseptual(Runco \& Acar, 2012).

\section{METODOLOGI}

Penelitian ini menggunakan metode kualitatif. Metode kualitatif berorientasi pada fenomena atau gejala yang terjadi disekitar atau lingkungan. Sedangkan pendekatan yang digunakan dalam penelitian kualitatif ini menggunakan pendekatan eksperimen yang bertujuan untuk mencari kondisi tertentu setelah diberi pengaruh dalam kondisi yang terkendalikan. Tujuan penelitian ini adalah mengetahui efektifitas SRP dalam meningkatkan keterampilan Bahasa dan Komunikasi sosial anak AUD autis. Subjek dalam penelitian ini anak perempuan dengan ASD berusia 4 tahun 7 bulan, anak pertama dari dua bersaudara, memiliki seorang adik laki-laki berusia 1 tahun. Saat ini Bulan belum mengikuti kegiatan sekolah, orang tua fokus untuk pelaksaan terapi yaitu Sensori Integrasi dan Terapi Perilaku untuk meningkatkan keterampilan perkembangan yang dibutuhkan saat anak sekolah.

Desain penelitian eksperimen yang digunakan dalam penelitian ini adalah Single Subject Research (SSR) dengan jenis subjek tunggal (single subject design). Peneliti menggunakan metode eksperimen subjek tunggal karena penelitian melibatkan anak berkebutuhan khusus lebih bisa diupayakan untuk menyelesaikan masalah pendidikan dan 
perkembangan anak dan mengetahui seberapa besar pengaruh dari suatu intervensi (treatment) yang diberikan secara berulang-ulang dalam waktu tertentu. Desain penelitian eksperimen dibedakan menjadi dua kelompok yaitu: Desain kelompok (group desain) yaitu memfokuskan pada data yang berasal dari kelompok individu. Desain ini digunakan untuk membandingkan kinerja (performance) antar kelompok individu. Desain subjek tunggal (single subject design) memfokuskan pada data individu sebagai sampel penelitian. Desain penelitian yang digunakan dalam penelitian ini adalah pola A-B-A sebagaimana disajikan pada gambar 1.

\section{Baseline $1 \longrightarrow$ Intervensi atau pengukuran $\longrightarrow$ Baseline 2}

\section{Gambar 1. Rancangan Penelitian}

Desain pola A-B-A-B memiliki 4 fase. Desain A-B-A -B merupakan salah satu pengembangan dari desain dasar A-B, desain A-B-A-B ini menunjukkan adanya kontrol terhadap variabel bebas yang lebih kuat. Serta menunjukkan hubungan fungsional antara variabel terikat dan bebas yang lebih meyakinkan. Dengan membandingkan dua kondisi baseline sebelum dan sesudah intervensi keyakinan adanya pengaruh intervensi lebih baik. Prosedur dasarnya tidak banyak berbeda dengan desain A-B, hanya saja telah ada pengulangan fase baseline dan intervensi.

Diawali dengan mengukur target Bahasa dan komunikasi sosial secara kontinu pada kondisi baseline pertama (A1) dengan periode waktu tertentu dilakukan intervensi (B). Berbeda dengan desain A-B, pada desain A-B-A-B setelah pengukuran kondisi intervensi (B) lalu pengukuran kondisi baseline kedua (A2) diberikan kemudian dilanjutkan dengan intervensi kedua (B2). Penambahan kondisi baseline kedua (A2) dan intervensi kedua (B2) ini dimaksudkan sebagai kontrol untuk fase intervensi sehingga memungkinkan untuk menarik kesimpulan adanya hubungan fungsional antara variabel bebas dan variabel terikat.

Variabel-variabel yang diteliti termasuk variabel bebas dan variabel terikat sudah ditentukan secara tegas oleh peneliti sejak awal penelitian. Dalam penelitian ini variabel bebas (independent variable) adalah Pendekatan SRP (Son-Rise Program), sedangkan variabel terikatnya (dependent variable) adalah keterampilan Bahasa dan komunikasi sosial. Sebelum melakukan treatment atau intervensi, peneliti telah menentukan target intervensi/ kegiatan yang akan diamati perubahannya. SRP saat keadaan non treatment diberi simbol " $\mathrm{A}$ " dan saat keadaan treatment diberi simbol "B". Kemudian merencanakan kegiatan SRP. Berdasarkan desain penelitian subjek tunggal maka sampel penelitian yang diambil adalah seorang anak ASD usia dini yang memiliki hambatan Bahasa dan komunikasi sosial berdasarkan hasil penilaian dan rekomendasi koordinator terapis di center tersebut.

Penelitian kualitatif merupakan pendekatan yang menekankan pada hasil pengamatan peneliti, sehingga peran peneliti sebagai instrument penelitian menjadi suatu keharusan bahkan dalam penelitian kualitatif posisi peneliti menjadi instrument key (instrument kunci). Untuk itu validitas dan reabilitas data kualitatif banyak tergantung pada keterampilan metodologis, kepekaan dan integritas peneliti itu sendiri. Peneliti bertindak sebagai pengamat dan partisipan aktif dalam proses pengumpulan data yang dilakukan dengan observasi dan wawancara. Maka untuk itu peneliti harus bersikap sebaik mungkin, hati-hati dan bersungguh-sungguh dalam proses pengumpulan data tersebut.

Peneliti dibantu oleh terapis sebagai kolaborator penelitian sebagai pelaksana harian dalam penelitian ini. Dan pengamatan, penilaian SRP akan dilakukan secara berkala oleh peneliti. Terapis tersebut memiliki latar belakang dari Pendidikan Luar Biasa dan memiliki jenjang Senior Therapies. Pengalaman bekerja sejak center didirikan yaitu tahun 2012, salah satu terapis senior yang sangat cekatan dan handal untuk dapat melaksanakan Son Rise Program kepada subjek penelitian. Terapis tersebut juga terkenal hangat dengan anak-anak yang sudah 
menjadi klien di Center tersebut, dan sangat informatif kepada orang tua dalam memberikan masukan dan penguatan bagi orang tua .

Teknik pengumpulan data dalam penelitian adalah observasi, metode atau cara-cara menganalisis dan mengadakan pencatatan secara sistematis mengenai tingkah laku dengan melihat atau mengamati individu atau kelompok secara langsung. Dengan demikian metode observasi ini dilakukan untuk mengetahui dan mendapatkan informasi lebih dekat dan rinci tentang objek yang diteliti. Peneliti melakukan pengamatan langsung terhadap anak dalam 3 kali pertemuan untuk melihat performa anak saat ini. Lembar kuesioner dan hasil pengamatan digunakan untuk analisis data tahap awal sebagai acuan penyusunan program kegiatan.

Teknik pengumpulan data berikutnya adalah wawancara, percakapan dengan maksud tertentu. Percakapan itu dilakukan oleh dua pihak, yaitu pewawancara yang mengajukan pertanyaan dan terwawancara yang memberikan jawaban atas jenis wawancara yang digunakan peneliti adalah wawancara semi terstruktur. Wawancara semi terstruktur termasuk dalam kategori in-depth interview dimana dalam pelaksanaannya lebih bebas bila dibandingkan dengan wawancara yang terstruktur. Wawancara jenis ini bertujuan untuk menemukan permasalahan secara lebih terbuka sehingga pihak yang diajak wawancara akan diminta pendapat, dan ide-idenya kemudian peneliti perlu mendengarkan dengan seksama dan mencatat apa yang dikemukakan oleh informan. Pada penelitian ini, peneliti juga menggunakan lembar kuesioner yang disajikan dalam format berupa indikator keterampilan yang dikuasai oleh anak. Lembar diberikan dan diisi langsung oleh orang tua .

Terakhir adalah dokumentasi, yaitu alat bantu yang digunakan peneliti untuk mengumpulkan data-data berupa buku-buku catatan atau sumber-sumber tertulis lainnya yang digunakan untuk penelitian serta dokumentasi visual maupun audio visual. Dalam hal ini yang menjadi sumber dokumentasi adalah proses atau respon subjek terhadap aktifitas SRP, peningkatan keterampilan Bahasa dan komunikasi sosial subjek.

Penelitian ini diawali dengan observasi untuk mencari subjek penelitian, ditemukan subjek yang orang tuanya belum memahami tentang SRP, dan telah memiliki pengalaman melakukan beberapa jenis terapi untuk anak. Peneliti menghubungi orang tua yang selanjutnya mengadakan pertemuan untuk diberikan penjelasan tentang SRP, tujuan kegiatan SRP, serta menjelaskan tentang prinsip SRP yang perlu dilakukan orang tua di rumah. Peneliti membuat kesepakatan bahwa kegiatan penelitian diadakan di Center setiap hari selama 20 hari berturut-turut dengan kegiatan baseline (A1) 3 hari, Intervensi (B1) 8 hari, baseline (A2) 3 hari dan intervensi (B2) 6 hari. Kegiatan SRP juga dilakukan di rumah setidaknya sekitar satu jam setiap hari. Peneliti juga melakukan pelatihan khusus mengenai Teknik pelaksanaan SRP untuk terapis sebagai kolaborator dalam penelitian ini sebelum penelitian dimulai. Orang tua juga diarahkan memberikan pendampingan pada anak di rumah melalui prinsip SRP.

Baseline adalah kondisi atau fase pengukuran variabel terikat atau target perilaku dimana anak belum mendapat intervensi. Pengukuran baseline ini dilakukan oleh peneliti bersama terapis dengan melakukan observasi. Pengukuran baseline menggunakan data pendukung yang diambil sebelum kegiatan observasi atau assessment dilakukan yaitu wawancara orang tua, angket orang tua yang berisikan data lengkap anak. Selanjutnya pengamatan dilakukan oleh peneliti dan terapis, masing-masing pengamat mencatat hasil pengamatnnya pada format yang sudah disediakan. Kegiatan observasi ini dilakukan 3 kali pertemuan untuk mendapatkan performa anak yang tepat sebelum diberikannya intervensi SRP oleh terapis.

Pada fase intervensi, pengukuran terhadap variabel terikat dilakukan pada saat intervensi diberikan. Pada tahap intervensi ini prosedur pelaksanaannya hampir sama seperti tahap baseline yaitu menyiapkan ruang belajar, media, dan kebutuhan lainnya dalam SRP serta format penilaian kegiatan SRP. Perbedaannya pada tahap ini peneliti dibantu oleh terapis sebagai kolaborator penelitian sebagai pelaksana harian dalam penelitian ini yang 
sudah diberikan pelatihan dan penjelasan mengenai SRP. Kegiatan dilakukan sepenuhnya mengikuti prinsip SRP. Indikator penilaian dalam penelitian ini adalah frekuensi yaitu berapa sering muncul dan minat anak melakukan kegiatan, pengamatan dan penilaian dalam kegiatan harian SRP akan dilakukan oleh terapis dan secara berkala akan dilakukan oleh peneliti.

Dalam penerapan SRP, terapis perlu melaksanakan prinsip dasar yitu; (1) Pendekatan yang berpusat pada anak dan membangun interaksi sosial dengan memberikan motivasi kepada anak, (2) Memberikan kontrol: Interaksi yang responsif dan peka terhadap anak menjadi faktor yang terpenting kedua dalam SRP dalam memfasilitasi munculnya minat yang spontan. Dalam SRP kegiatan berpusat pada anak, ini berarti a) Topik permainan berasal dari minat anak, b) Anak akan aktif untuk menentukan kapan memulai maupun mengakhiri interaksi, (3) Sikap positif yang memfasilitasi hubungan sosial yang lebih intim, hal ini dilakukan dengan dua alasan, yaitu; Penerimaan dan Mendorong anak untuk terlibat. (4) Bergabung dengan perilaku eksklusif dan berulang untuk membangun interaksi sosial. Prinsip inti SRP adalah kegiatan terpusat pada anak dan responsive terhadap koneksi yang terbangun dari interaksi sosial yang membedakan dari pendekatan lainnya. Serta teknik dalam Son-Rise Program yaitu; (a) Celebrating/Responding to Green Light for Interaction, (b) Membangun/ Building, (c) Memulai/ Initiating, (d) Meminta/ Requesting

Dalam penelitian ini instrument yang digunakan mulai dari program kegiatan, Program individual, format penilaian mengikuti apa yang ditetapkan oleh Son-Rise Program (SRP). Peneliti hanya perlu menyadur dalam Bahasa Indonesia atau memberikan pemahaman kepada terapis agar lebih dipahami. Dan penulisan laporan harian akan dibuat menggunakan Bahasa Indonesia. Program SRP digunakan sebagai acuan oleh peneliti untuk melakukan observasi dan asesmen diawal kegiatan penelitian untuk dapat menentukan baseline (A1). Format ini akan digunakan untuk menggambarkan program kegiatan SRP yang akan dilakukan anak berada ditingkatan tertentu dan untuk mengamati kelanjutan program berikutnya jika program sebelumnya sudah tercapai atau terpenuhi. Menentukan tingkat kemampuan anak saat observasi atau asesmen berdasarkan hasil wawancara dengan orang tua dan Analisa awal peneliti. Tabel 1 (lampiran) adalah Program Son Rise yang dikutip dari Autism Treatment Center of America, $4^{\text {th }}$ Edition (2016);

Format Program ini dibuat untuk setiap individu setelah dilakukan asesmen dan mengacu kepada kurikulum atau Program Son-Rise. Program individual ini menjadi target yang akan dicapai dalam penelitian ini disajikan pada tabel 2. Dalam penelitian ini dilakukan evaluasi tengah program atau observasi kegiatan yang telah dilakukan dengan mengamati beberapa hal terkait kegiatan yang sudah dilaksanakan 20 jam pertemuan sebelumnya. Evaluasi tengah program dilakukan oleh supervisor program atau case manager, bertujuan memberikan control terhadap program tersebut untuk mencapai keberhasilan program yang direncanakan. Dalam evaluasi tengah program dilakukan konferensi yang melibatkan orang tua dan terapis serta supervisor, hal ini dilakukan agar semua memahami dan melakukan perannya dalam pelaksanaan program selanjutnya. Format penilaian disajikan pada tabel 3 (lampiran 2).

Penelitian yang dilakukan menggunakan validitas isi sebelum instrumen diberi penilaian oleh para ahli untuk meningkatan validitas penelitian dengan menggunakan desain A-B-A-B, maka peneliti melaksanakan pengukuran dan pencatatan data pada kondisi baseline (A) dalam waktu tiga atau lima kali dan/atau sampai kondisi baseline stabil. Kondisi stabil dapat dilihat dari jejak data nilai selalu sama atau tidak terlalu jauh nilainya. Desain A-BA-B ada pengulangan pengukuran, dimana baseline (A) dan intervensi (B) yang telah dilakukan pengukuran pada subjek yang sama, diulang kembali pada baseline (A) dan intervensi (B) dengan demikian ada pengaruh intervensi terhadap variabel terikat, sehingga perubahan pada target penelitian terkontrol. Desain A-B-A-B juga dimungkinkan adanya kontrol terhadap variabel bebas yang lebih kuat dibandingkan dengan desain A-B atau A-B-A. validitas internal juga akan lebih meningkat, sehingga penelitian yang menunjukan 
hubungan fungsional antara variabel terikat dan bebas lebih meyakinkan. Dengan membandingkan dua kondisi baseline sebelum dan sesudah intervensi keyakinan ada pengaruh intervensi lebih valid.

Tabel 2. Program Individual

Nama Anak

PROGRAM GOALS

Periode

Tempat Tanggal Lahir :

Terapis

Nama Orang tua

Penanggung Jawab Program :

\begin{tabular}{lcccc}
\hline \multicolumn{4}{c}{ Area } \\
\hline $\begin{array}{l}\text { Area } \\
\text { Pembelajaran }\end{array}$ & $\begin{array}{c}\text { Kontak mata \& } \\
\text { Vomikasi Non- }\end{array}$ & $\begin{array}{c}\text { Komunikasi } \\
\text { Verbal }\end{array}$ & $\begin{array}{c}\text { Rentang } \\
\text { perhatian }\end{array}$ & Fleksibilitas \\
\hline Tujuan & & & \\
\hline Teknik & & & \\
Pembelajaran & & & \\
\hline
\end{tabular}

\section{HASIL DAN PEMBAHASAN}

Penelitian dilaksanakan lembaga tumbuh kembang anak yang memiliki visi untuk membantu orang tua dan keluarga dalam mendampingi anak berkebutuhan khusus untuk meningkatkan perkembangan yang lebih optimal. Serta misi yang mampu memberikan pelayanan terbaik, sarana dan prasarana yang baik yang dibutuhkan untuk mengembangkan keterampilan anak, memberikan dukungan kepada keluarga untuk dapat melakukan dukungan yang optimal untuk anak mereka di rumah. Penelitian ini dilaksanakan dalam 20 pertemuan, mulai dari perencanaan kegiatan SRP dengan observasi, mengumpulkan informasi dan identifikasi kondisi awal subjek. Pelaksanaan SRP yang dilakukan oleh kolaborator, pelaksanaan kegiatan SRP dalam 2 sesi intervensi.

Observasi sebagai baseline (A) yaitu pre-test sebelum ada intervensi, pada baseline (A1) diawal nampak anak memahami dan merespon dengan tepat instruksi yang diberikan oleh terapis hanya saja masih dengan arahan, perlu pengulangan instruksi bahkan memberikan bantuan gesture atau modeling agar anak dapat merespon terapis. Anak belum mampu merespon instruksi atau pengarahan dari guru secara runut, respon dilakukan sesuai dengan minat anak saja. Keinginan sesaat yang tidak terpenuhi membuat anak menjadi sangat agresif karena anak kesulitan untuk mengekspresikan keinginannya. Anak sulit untuk dikendalikan saat kegiatan karena kesulitan memahami arahan yang diberikan saat perasaannya tidak nyaman sehingga keinginan sesaatnya harus terpenuhi segera. Saat marah anak banyak mengeluarkan suara seperti jargon yang bermakna tetapi tidak sesuai dengan situasi saat itu. Anak juga mengulang kata-kata yang biasa diucapkan saat anak marah.

Anak mampu berujar kata sederhana, anak juga mampu spontan mengidentifikasi benda-benda disekitarnya saat bermain, hanya saja dalam bahasa Inggris. Kemampuan mengidentifikasi benda yang ada disekitar mulai berkembang, anak mampu mengenal lebih dari 10 benda yang dilihatnya, hanya saja belum konsisten. Anak mampu berekspresi secara verbal untuk mengungkapkan keinginan sederhana nya dengan kata "itu, itu, itu" atau "simpan" yang bermakna bahwa dia tidak mau melakukan sesuatu yang diinstruksikan terapis. Biasanya diawali dengan bahasa tubuh seperti menunjuk atau menarik, berusaha sekeras mungkin mendapatkan apa yang diinginkannya. Kemampuan artikulasinya cukup 
berkembang dengan baik, hanya saja terkadang rancu dengan artikulasi Bahasa Inggris, karena anak sering menggunakan Bahasa Inggris dalam interaksi komunikasi nya.

Pada Anak mampu mengikuti kegiatan yang diarahkan terapis hanya saja masih dengan rentang atensi yang pendek sekitar 2-5 menit, anak sering beralih perhatian kepada hal-hal yang lebih menarik perhatian. Anak mengikuti arahan terapis untuk melakukan tugastugas sesuai tuntutan. Beberapa kegiatan bermain yang sering dilakukan sebelumnya di rumah, dilakukan anak dengan pola yang kaku, terapis kesulitan untuk terlibat dalam interaksi kegiatan bermain Bersama anak, anak selalu ingin bermain dengan caranya sendiri, dan menolak interaksi dari orang lain.

Anak masih belum mampu mengekspresikan emosinya dengan tepat, hal ini terlihat saat keinginan sesaatnya tidak terpenuhi anak akan menangis bahkan tidak terkontrol hingga keinginannya terpenuhi. Anak tidak melakukan Tindakan yang akan melukai dirinya atau orang lain dilingkungan, anak hanya berteriak dan mengujarkan kata-kata tertentu dan berulang. Anak akan bertahan dengan waktu yang panjang dengan perilakunya tersebut untuk mendapatkan apa yang diinginkannya. Anak juga masih belum memahami aturan, dan masih sulit mengikuti aturan dan arahan dalam kegiatan. Anak masih asik dengan diri nya sendiri dan kegiatan yang disenanginya saat itu.

Anak cukup memahami emosi orang lain seperti terapis suka dan tidak suka, atau larangan. Jika terapis memunculkan emosi tidak suka, ia akan meninggalkan situasi itu, seperti tidak mau ada konflik atau mengabaikan situasi. Hanya saja jika terapis berekspresi senang atau suka, tidak ada respon yang berlebih dari anak. Anak juga terlihat tidak tertarik untuk berbagi mainan dengan guru, jika terapis mengambil mainan anak dan anak tidak berusaha untuk mengambil atau merebutnya kembali. Anak akan berusaha mendapatkannya dengan cara yang berbeda seperti saat guru lengah dengan mainan tersebut atau anak menjadi marah jika mainan yang diambil adalah mainan yang sangat anak sukai.

Berdasarkan hasil pengamatan kondisi awal keterampilan bahasa dan sosial anak, peneliti dapat menuliskan kondisi awal anak berdasarkan penilaian awal sesuai indikator yang akan diamati dan dikembangan dalam SRP. Pada kondisi awal anak hampir semua indikator memiliki penilaian 1 yaitu anak belum memiliki minat dalam kegiatan dan mampu diarahkan dan diberikan stimulasi motivasi untuk dapat melakukan kegiatan yang diarahkan. Hanya pada indikator fleksibilitas memiliki penilaian kondisi awal 0 yaitu anak belum menunjukan respon yang sesuai, kemampuan anak tidak muncul sebagaimana disajikan pada tabel 4 .

Tabel 4. Kondisi baseline (A1)

\begin{tabular}{ccc}
\hline Keterampilan & \multicolumn{2}{c}{ Baseline (A1) } \\
& $\begin{array}{c}\text { Frekuensi } \\
\text { (F) }\end{array}$ & $\begin{array}{c}\text { Minat } \\
(\mathbf{M})\end{array}$ \\
\hline Interactive Attention Span & 0 & 1 \\
Eye Contact \& Non- Verbal Comm & 0 & 1 \\
Flexibility & 0 & 0 \\
Verbal Communication & 1 & 1 \\
\hline
\end{tabular}

Dalam pelaksanaan SRP terapis melakukan menawarkan permainan sesuai dengan target atensi yang akan dicapai oleh anak yaitu 5-9 menit berarti sekitar 10 kali terapis menawarkan permainan dalam satu jam kegiatan. Indikator penilaian dalam penelitian ini adalah frekuensi pencapaian keterampilan dan minat anak dalam melakukan dan merespon kegiatan. Berikut adalah penilaian terhadap indikator frekuensi; (3) anak mampu melakukan keterampilan 60-80\% dari total kegiatan yang ditawarkan terapis. (2) anak mampu melakukan keterampilan 40-60\% dari total kegiatan yang ditawarkan terapis. (1) anak mampu melakukan keterampilan 20-40\% dari total kegiatan yang ditawarkan terapis. (0) anak mampu melakukan keterampilan dibawah $20 \%$ dari total kegiatan yang ditawarkan terapis. Penilaian terhadap 
indikator minat yaitu; (3) Anak memiliki minat yang baik dalam berinteraksi dan melakukan kegiatan dan mampu membangun interaksi dengan terapis dengan mandiri. (2) Anak memiliki minat yang baik dalam melakukan kegiatan hanya perlu arahan atau stimulasi verbal untuk mengikuti kegiatan dalam interaksi bersama terapis. (1) Anak belum memiliki minat dalam kegiatan dan mampu diarahkan dan diberikan motivasi untuk dapat melakukan kegiatan yang diarahkan. (0) Anak belum menunjukan respon yang sesuai, minat anak tidak muncul, sebagaimana disajikan pada tabel 5 (Lampiran 3).

Pelaksanaan SRP sebagai intervensi (B) dilakukan sesuai dengan perencanaan yang telah dibuat berdasarkan kemampuan awal anak. 1. Terapis mendorong anak untuk melihat dengan ekspresi wajah pada orang lain seperti, mengedipkan mata, kaget dengan membuka mulut dan lainnya yang dapat mewakili emosinya saat itu. Pelaksanaan kegiatan dengan memposisikan level mata sejajar atau dibawah anak, memudahkan anak untuk melihat kearah terapis. Memberikan perhatian pada anak dengan menerima apa yang dilakukannya. Memberikan ekspresi mimik wajah untuk memberikan makna terhadap perasaan yang dirasakan terapis, sehingga anak belajar mengidentifikasi mimik wajah tersebut sehingga bermakna sesuai situasi dan kondisi saat itu. Memberikan penghargaan dengan merespon setiap kali anak memberikan mimik wajah yang mewakili perasaannya kepada terapis.

Target komunikasi verbal yaitu meningkatkan kemampuan pemahaman kata sehingga anak memiliki perbendaharaan kata sekitar 6-50 kata atau lebih. Pelaksanaan kegiatan dengan memposisikan diri sebaik yang bisa dilakukan untuk mendapatkan kontak mata dengan anak saat berinteraksi. Memberikan kata yang bermakna di setiap benda atau mainan yang sedang dieksplorasi oleh anak atau suara bermakna yang mewakili emosi saat itu (misalnya kaget, bahagia atau senang, sedih dan lainnya dengan ekspresi mimik wajah). Berhenti sementara untuk mengatakan apa pun dan menunggu sampai anak merespon terapis sebelum melanjutkan bicara atau berkata-kata lagi. Menggunakan suara, wajah dan gerakan yang menarik ketika berinteraksi dengan anak (bisa dengan suara yang bukan suara biasanya). Selalu mengarahkan atensi dalam setiap interaksi kedalam kontak mata.

Target rentang perhatian interaktif yaitu; mendorong anak untuk memperpanjang rentang atensi nya sekitar 5-9 menit dalam setiap kegiatan. Pelaksanaan kegiatan dapat dilakukan dengan memberikan cara yang mudah untuk anak berpartisipasi dalam kegiatan. Memberikan sesuatu mainan yang anak senangi sebelum meminta anak melakukan apa pun yang ingin dia lakukan (misalnya, jika terapis memulai satu permainan, berikan anak giliran untuk melakukannya untuk beberapa waktu sebelum mengarahkan nya untuk berkata "mau lagi". Persisten, jika anak sudah mulai ingin meninggalkan terapis dan kegiatannya, memanggil dia kembali dengan cara yang sangat playfull sampai dia kembali tertarik dan mau melakukannya lagi. Jika anak menyebutkan nama-nama mainan yang sedang dipegangnya, bergabung dan membangun satu kegiatan baru yang lebih bermakna daripada hanya sekedar menyebutkan satu persatu nama benda yang dia pegang.

Pada target fleksibilitas, membantu anak untuk terlibat dalam permainan dengan peraturan sederhana dan terstruktur. Pelaksanaan kegiatan dengan memuji anak setiap ia berpartisipasi dalam kejadian atau kegiatan permainan. Terapis perlu menjadi fleksibel saat berinteraksi dengan anak. Memberikan saran permainan terstruktur pada anak, model permainan terstruktur. Pengamatan hasil belajar harian yang dilakukan dalam 10 pertemuan. Kegiatan dilakukan merujuk pada 4 indikator yang tercantum dalam program kegiatan SRP. Dari awal kegiatan SRP anak diarahkan untuk masuk kedalam ruangan sampai akhirnya anak menantikan kegiatan SRP dan mandiri masuk kedalam ruang, saat anak dipersilahkan masuk. Anak terlihat lebih aktif dalam bicara, meskipun baru sebatas identifikasi benda-benda yang dikenal oleh anak. Dan anak mulai melakukan permainan interaktif dengan meniru apa yang dilakukan oleh terapis dalam kegiatan bermain SRP. Rentang atensi anak mulai berkembang seiring minat terhadap kegiatan meninggkat, dan anak mulai menunjukan minat interaksi dengan membangun kontak mata dengan terapis meskipun masih belum optimal. 
Tabel 6. Baseline (A1)

\begin{tabular}{lcccccc}
\hline \multicolumn{1}{c}{ Keterampilan } & \multicolumn{3}{c}{1} & \multicolumn{2}{c}{2} & \multicolumn{2}{c}{3} \\
& F & M & F & M & F & M \\
\hline Interactive Attention Span & 0 & 1 & 0 & 1 & 0 & 1 \\
Eye Contact \& Non- Verbal & 0 & 1 & 0 & 1 & 0 & 1 \\
Comm & 0 & 0 & 0 & 0 & 0 & 0 \\
Flexibility & 0 & 1 & 1 & 1 & 1 & 1 \\
Verbal Comm & 1 & 1
\end{tabular}

Tabel 7. Intervensi (B1)

\begin{tabular}{|c|c|c|c|c|c|c|c|c|c|c|c|c|c|c|c|c|}
\hline \multirow{2}{*}{ Keterampilan } & \multicolumn{2}{|c|}{4} & \multicolumn{2}{|c|}{5} & \multicolumn{2}{|c|}{6} & \multicolumn{2}{|c|}{7} & \multicolumn{2}{|c|}{8} & \multicolumn{2}{|c|}{9} & \multicolumn{2}{|c|}{10} & \multicolumn{2}{|c|}{11} \\
\hline & $\mathbf{F}$ & $\mathbf{M}$ & $\mathbf{F}$ & $\mathbf{M}$ & $\mathbf{F}$ & $\mathbf{M}$ & $\mathbf{F}$ & $\mathbf{M}$ & $\mathbf{F}$ & $\mathbf{M}$ & $\mathbf{F}$ & $\mathbf{M}$ & $\mathbf{F}$ & $\mathbf{M}$ & $\mathbf{F}$ & $\mathbf{M}$ \\
\hline Interactive & & & & & & & & & & & & & & & & \\
\hline $\begin{array}{l}\text { Attention } \\
\text { Span }\end{array}$ & 1 & 1 & 1 & 2 & 1 & 2 & 2 & 2 & 2 & 2 & 2 & 2 & 2 & 3 & 2 & 3 \\
\hline Eye Contact \& & & & & & & & & & & & & & & & & \\
\hline $\begin{array}{l}\text { Non- Verbal } \\
\text { Comm }\end{array}$ & 1 & 1 & 1 & 1 & 1 & 2 & 1 & 2 & 1 & 2 & 1 & 2 & 2 & 2 & 2 & 2 \\
\hline Flexibility & 0 & 0 & 0 & 0 & 0 & 0 & 0 & 1 & 0 & 1 & 0 & 1 & 0 & 1 & 0 & 1 \\
\hline Verbal Comm & 1 & 1 & 1 & 1 & 1 & 1 & 1 & 2 & 1 & 2 & 1 & 2 & 2 & 2 & 2 & 2 \\
\hline
\end{tabular}

Tabel 6 dan 7 menunjukkan hasil pencapaian kegiatan pada 4 area keterampilan yang diukur berdasarkan frekuensi kemunculan saat kegiatan dan minat yang ditunjukan oleh anak. Terlihat bahwa pada kondisi baseline (A1), anak masih menunjukan kemampuan yang masih kurang dan baru berkembang dari semua area keterampilan SRP. Pada kondisi intervensi (B1) menunjukan peningkatan yang cukup konsisten, pencapaiannya terus meningkat setiap hari nya dan cenderung konsisten. Hanya pada area keterampilan fleksibility yang belum menunjukan peningkatan yang konsisten.

Dalam sesi pertama ini perubahan yang terjadi adalah anak terlihat sangat senang untuk mengikuti kegiatan. Anak menjadi pribadi yang senang, ceria dan ramah untuk dapat membangun berinteraksi dengan lingkungannya. Orang tua menyadari bahwa anak mengalami banyak perubahan dari keterampilan sosial. Anak nyaman dengan kondisi di area umum, anak tidak marah saat mendengar kebisingan dan hiruk pikuk di area umum seperti area transportasi umum yang sering digunakan anak. Anak mau menunggu giliran untuk masuk kedalam kereta dan keluar dari kereta. Saat di rumah pun anak memiliki keteraturan sendiri saat bermain, tanpa diberikan instruksi anak mau merapikan mainan yang telah selesai dimainkan.

Saat menunggu waktu kegiatan, anak sudah mau berinteraksi dengan anak lain yang ada diruang tunggu tersebut, interaksi komunikasi anak semakin banyak dan konsisten, anak berujar tentang banyak hal seperti nama mainan yang dipegangnya. Dan kesadaran lingkungan anak mulai berkembang saat anak sadar bahwa adiknya dipangku terapis dan anak berkata "tidak mau" "kasih ibu" "ambil ibu" terus mengulang kata-kata tersebut sampai adiknya dikembalikan kepangkuan ibu nya. Anak juga menjadi sangat ramah dengan orangorang yang ditemui di center, menyapa semua orang saat anak dating begitu pula saat selesai kegiatan, anak berpamitan kepada semua orang yang ada di center dengan berkata "bulan pulang" "dadah dadah" "kiss bye" berulang-ulang sampai semua orang yang ada disekitarnya merespon dan kemudian meminta sepatu kepada ibu "mau sepatu".

Perubahan frekuensi dan perubahan minat pada setiap area keterampilan, disajikan dengan grafik pada gambar 2 dan 3. 


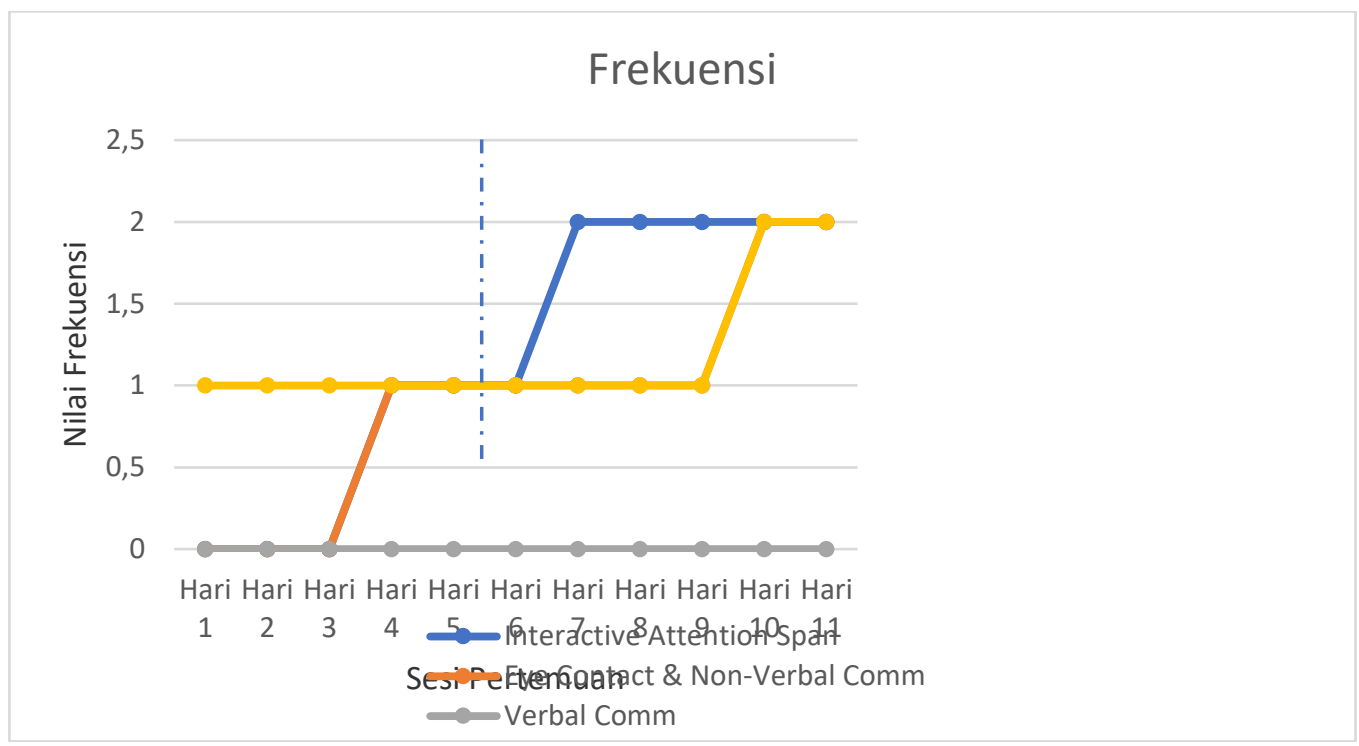

Gambar 2. Grafik Perubahan Frekuensi Pada Setiap Area Keterampilan (A1) \& (B1)

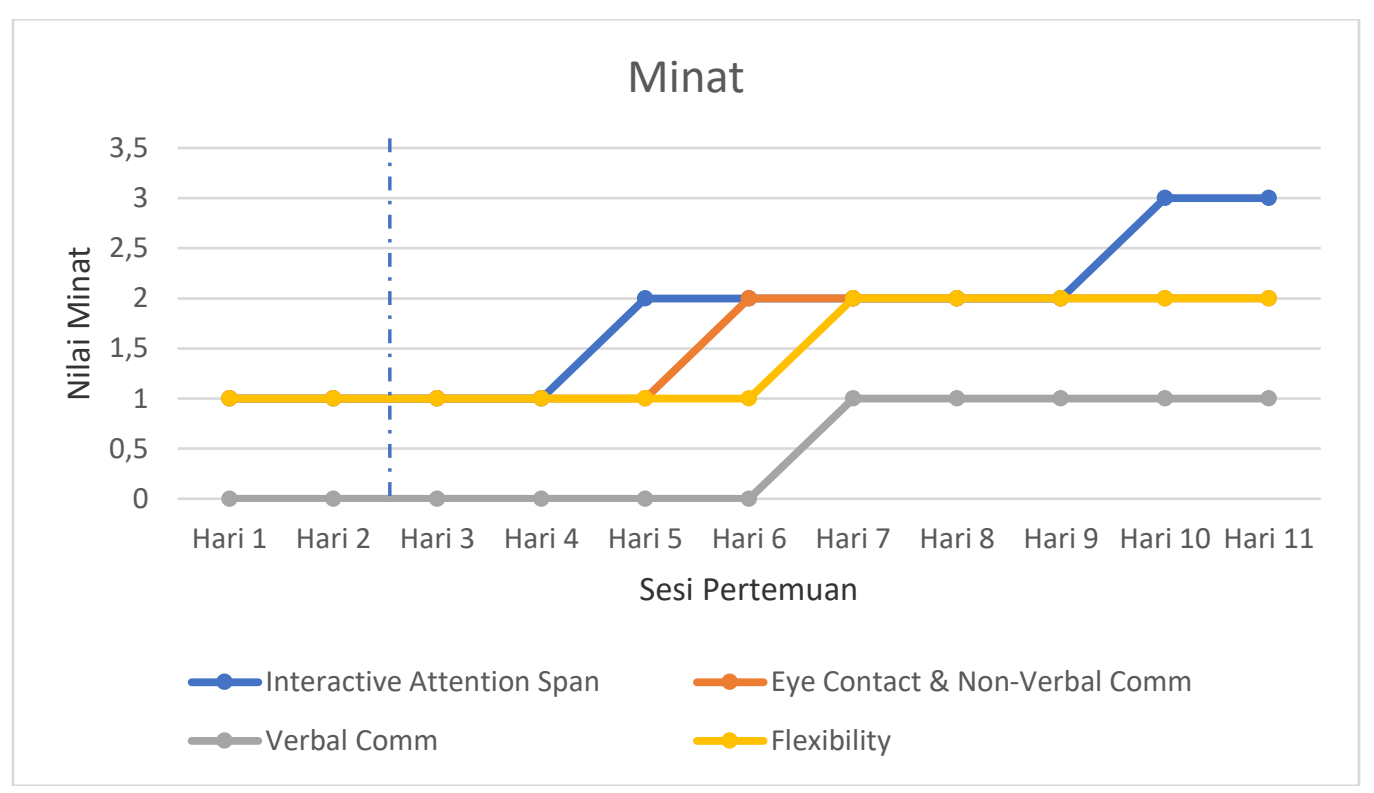

Gambar 3. Grafik Perubahan Minat Pada Setiap Area Keterampilan (A1) \& (B1)

Berikutnya adalah evaluasi kegiatan yang dilakukan setelah kegiatan intervensi (B1) dilakukan, untuk meninjau beberapa aspek kegiatan terkait aktifitas yang diminati anak, jenis mainan yang disukai oleh anak, cara yang paling efektif bagi anak untuk terlibat dalam kegiatan bersama terapis. Evaluasi ini dilakukan untuk menyiapkan kegiatan pada intervensi (B2) agar pencapaiannya lebih optimal. Hasil evaluasi ini juga akan menjadi bahan pembahasan dengan terapis dan peneliti serta orang tua, agar kegiatan selanjutnya dapat diupakayan Bersama lebih baik lagi.

Dalam sesi kedua, terapis akan mengupayakan fleksibilitas meningkat dalam setiap kegiatan. Tetap menumbuhkan minat anak dalam mengeksplorasi permainan-permainan baru serta meningkatkan atensi dalam setiap kegiatan. Terapis juga akan memperkenalkan permainan imajinatif lainnya melalui permainan yang diminatinya saat ini. Dan meningkatkan kemampuan mengenal benda atau barang-barang yang ada disekitar dengan cara yang menarik, sehingga anak akan menggunakan kata tersebut dalam interaksi komunikasi dengan lingkungan. Dalam putaran kedua nanti terapis akan mengupayakan menumbuhkan minat anak terhadap lingkungan lebih baik, anak mau membangun interaksi 
komunikasi tidak hanya saat butuh tetapi merespon interaksi orang lain menjadi perlu dilakukan dilingkungan sosial.

Tabel 8. Baseline (A2) \& Intervensi (B2)

\begin{tabular}{|c|c|c|c|c|c|c|c|c|c|c|c|c|c|c|c|c|c|c|}
\hline \multirow{2}{*}{ Keterampilan } & \multicolumn{2}{|c|}{12} & \multicolumn{2}{|c|}{13} & \multicolumn{2}{|c|}{14} & \multicolumn{2}{|c|}{15} & \multicolumn{2}{|c|}{16} & \multicolumn{2}{|c|}{17} & \multicolumn{2}{|c|}{18} & \multicolumn{2}{|c|}{19} & \multicolumn{2}{|c|}{20} \\
\hline & $\mathbf{F}$ & $\mathbf{M}$ & $\mathbf{F}$ & $\mathbf{M}$ & $\mathbf{F}$ & $\mathbf{M}$ & $\mathbf{F}$ & $\mathbf{M}$ & $\mathbf{F}$ & $\mathbf{M}$ & $\mathbf{F}$ & $\mathbf{M}$ & $\mathbf{F}$ & $\mathbf{M}$ & $\mathbf{F}$ & $\mathbf{M}$ & $\mathbf{F}$ & $\mathbf{M}$ \\
\hline $\begin{array}{l}\text { Interactive Attention } \\
\text { Span }\end{array}$ & 2 & 3 & 2 & 3 & 2 & 3 & 3 & 3 & 3 & 3 & 3 & 3 & 3 & 3 & 3 & 3 & 3 & 3 \\
\hline $\begin{array}{l}\text { Eye Contact \& Non- } \\
\text { Verbal Comm }\end{array}$ & 2 & 2 & 2 & 2 & 2 & 2 & 2 & 2 & 2 & 2 & 2 & 3 & 3 & 3 & 3 & 3 & 3 & 3 \\
\hline Flexibility & 1 & 1 & 1 & 1 & 1 & 1 & 1 & 1 & 1 & 1 & 1 & 1 & 1 & 1 & 1 & 1 & 1 & 1 \\
\hline Verbal Comm & 3 & 2 & 3 & 3 & 3 & 3 & 3 & 3 & 3 & 3 & 3 & 3 & 3 & 3 & 3 & 3 & 3 & 3 \\
\hline
\end{tabular}

Baseline kedua (A2) sebagaimana pada tabel 8, dilakukan dihari ke 12 hingga 14, konsistensi pencapaian kemampuan anak untuk menunjukan minat dan frekuensi cukup baik dan mulai meningkat perkembangannya dikondisi intervensi (B2) sebagaimana pada tabel 8, semakin konsisten. Hal ini dapat dilihat dengan rentang atensi interaktif anak berkembang sangat pesat, terlihat konsistensi yang muncul sepanjang kegiatan di sesi kedua menunjukan bahwa anak memiliki minat yang baik dalam berinteraksi dan melakukan kegiatan dan mampu membangun interaksi dengan terapis dengan mandiri. Anak terlihat sangat memiliki minat terhadap kegiatan bermain, anak sangat termotivasi dengan kegiatan permainan yang ditawarkan terapis. Anak selalu menikmati kegiatan bermainnya bersama terapis. Perkembangan kontak mata dan komunikasi non-verbal anak terlihat sangat berkembang dan mulai konsisten, hal ini terlihat anak memiliki minat yang baik dalam berinteraksi dan melakukan kegiatan dan mampu membangun interaksi dengan terapis dengan mandiri.

Kemampuan fleksibel pada anak anak terlihat tidak cukup berkembang secara berkelanjutan, tetapi anak terlihat konsisten untuk terlihat perubahan pada area ini, hal ini dilihat saat Anak belum memiliki minat dalam kegiatan dan mampu diarahkan dan diberikan stimulasi motivasi untuk dapat melakukan kegiatan yang diarahkan. Area komunikasi verbal menjadi area yang sangat memiliki perubahan pesat terlihat mulai pertemuan ke 14 anak menunjukan konsistensi terhadap perubahan yang baik, hal ini dilihat saat anak memiliki minat yang baik dalam berinteraksi dan melakukan kegiatan dan mampu membangun interaksi dengan terapis dengan mandiri. Selengkapnya disajikan dengan grafik pada gambar 4 dan 5.

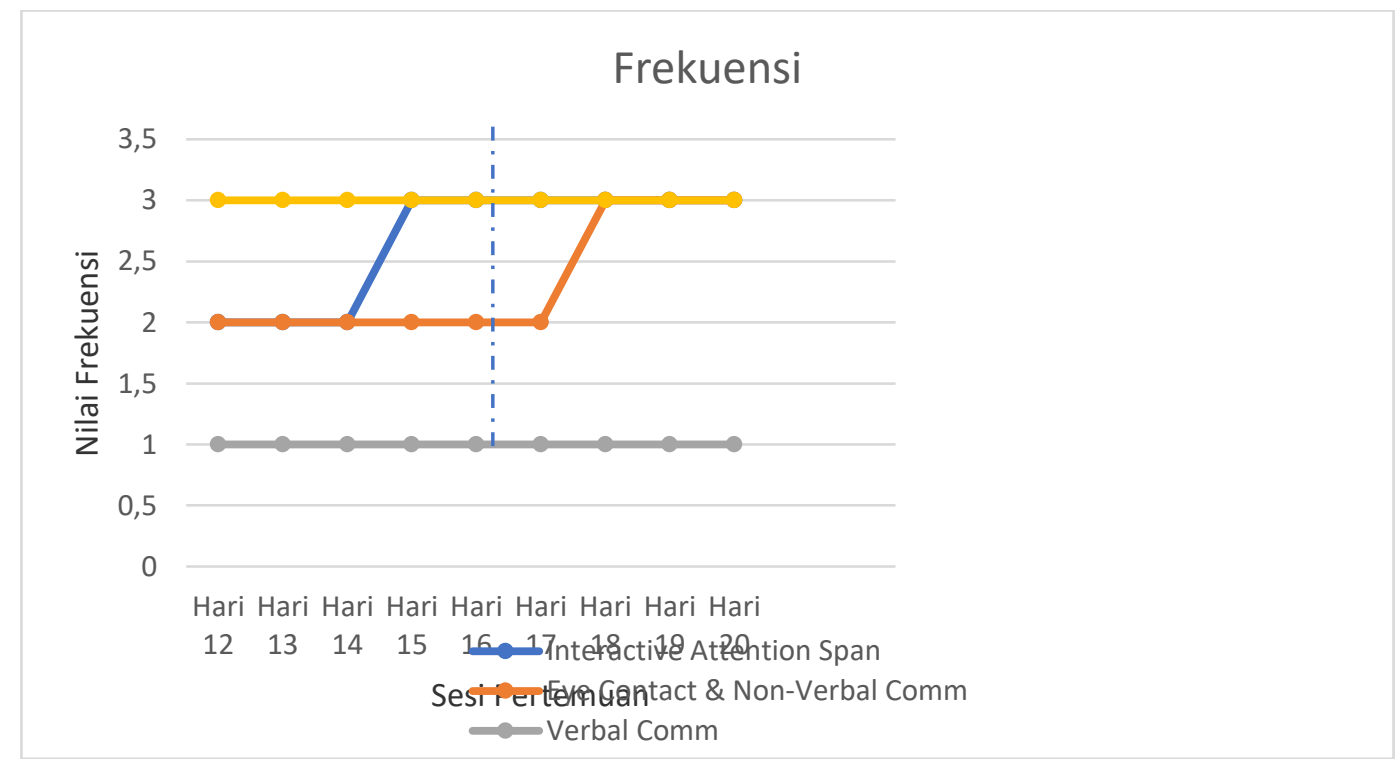




\section{Gambar 4. Grafik Perubahan Frekuensi Pada Setiap Area Keterampilan (A1) \& (B1)}

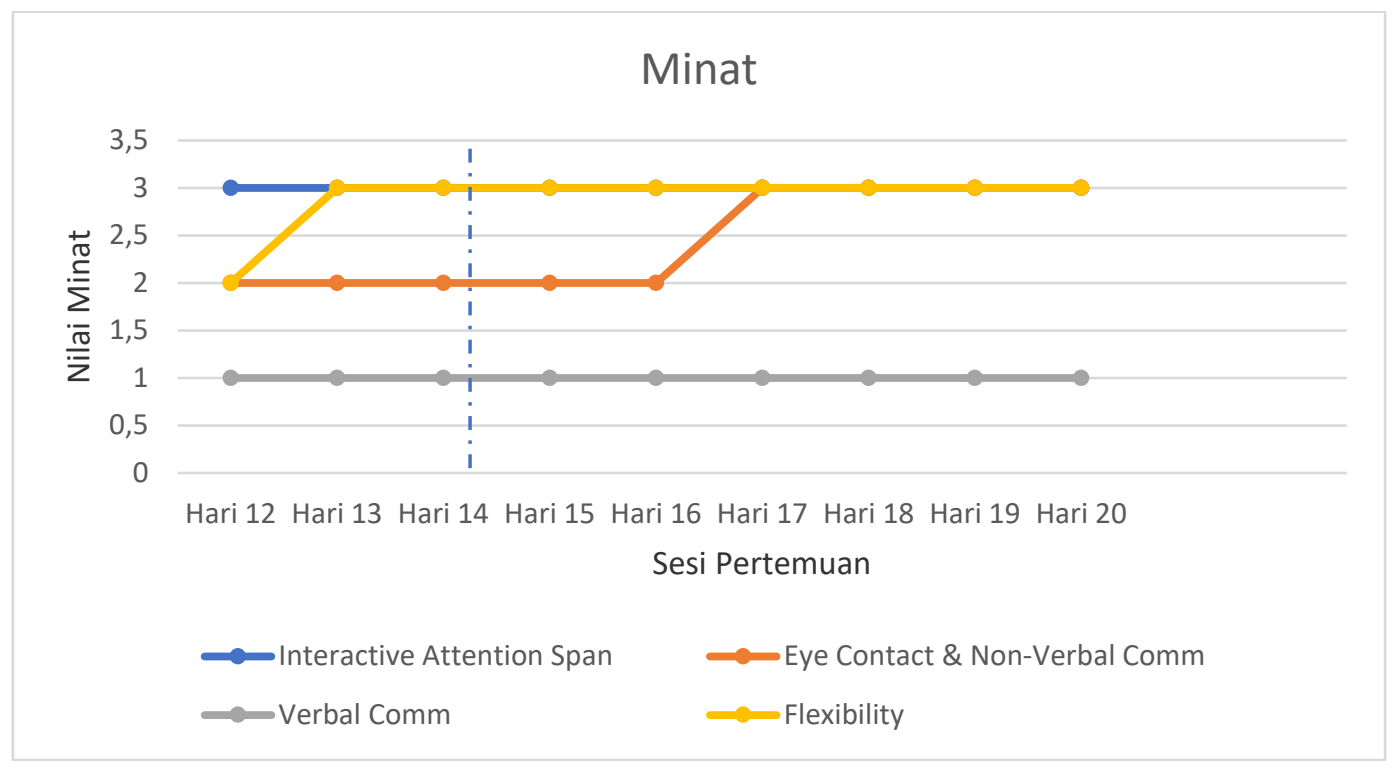

Gambar 5. Grafik Perubahan Minat Pada Setiap Area Keterampilan (A2) \& (B2)

Dalam sesi kedua nampak peningkatan yang sangat baik dalam keterampilan mempertahankan rentang atensi dan interaksi, kontak mata dan komunikasi non-verbal, keluesan dalam melakukan kegiatan, serta verbal komunikasi. Anak terlihat sangat interaktif dalam membangun hubungan dengan orang lain, meskipun terkadang masih diarahkan untuk memulai. Hanya saja anak pasti melakukan interaksi dengan lingkungan saat anak merasa membutuhkan sesuatu. Anak lebih ekspresif untuk mengungkapkan apa yang diinginkan dan apa yang tidak disukainya. Kesadaran anak terhadap lingkungan cukup baik, anak memahami apa yang salah yang terjadi dilingkungannya dan anak mampu merespon nya dengan tepat.

Anak juga sudah memahami dan mengekspresikan emosinya secara tepat dan wajar. Anak mampu memberikan respon yang tepat saat terapis menangis atau terluka. Anak akan mendekati dan memeluk. Hal ini juga terlihat saat adiknya digendong oleh terapis lain, rasa memiliki rasa saying sudah mulai muncul meskipun baru hal-hal yang terkait diri nya. Anak juga mampu mengekspresikan emosi dengan menangis atau merengek hanya saja sudah mulai bisa diarahkan dan diberi pengertian untuk berhenti menangis dan menunggu sampai ibu atau terapis melakukan apa yang diinginkannya. Hal ini tidak nampak diawal kegiatan $\mathrm{SRP}$, anak pernah menangis dan tidak mau mengikuti sesi observasi karena ada satu kegiatan yang dilewati oleh anak, hal tersebut membuat luka dan ketidak nyamanan perasaannya.

Pada area fleksibiliti yang terlihat perubahannya tidak cukup signifikan seperti perkembangan pada area lainnya. Dari awal anak terlihat sangat rigid tentang satu aturan, pembiasaan mau pun hal-hal lainnya yang sangat detail seperti waktu, posisi benda. Dengan anak mau mengikuti arahan kegiatan dan cara bermain yang baru merupakan hal luar biasa yang ditunjukan oleh anak. Anak mau merubah rutinitas dan kebiasaannya bermain dengan mengikuti cara bermain baru yang diberikan oleh terapis. Anak juga lebih fleksibel saat orang lain yang menyalakan lampu saat senja tiba. Anak juga tidak terlalu perduli jika ada posisi sepatu yang tidak sesuai urutan, anak merasa nyaman sejauh sepatu diletakan ditempatnya, semua dikembalikan pada tempatnya dan tidak perduli dengan urutan dan lainnya.

\section{Interpretasi Hasil Analisis Data}

Pada pelaksanaan intervensi sesi 1 (B1) dapat dilihat perubahan perkembangan yang terjadi berdasarkan indikator yang dicapai untuk meningkatkan keterampilan Bahasa dan sosial anak. Terlihat bahwa pada kondisi baseline (A1) anak menunjukan nilai pencapaian yang 
masih rendah dan setelah dilakukan intervensi SRP sesi 1 (B1) maka pencapaian meningkat dengan signifikan pada setiap indikator meskipun dalam prosesnya menjadi berbeda. Terlihat bahwa keterampilan fleksibilitas pada anak paling sulit untuk dikembangkan, anak terbiasa dengan pola aturan yang kaku dan rutinitas yang monoton sehingga anak hanya melakukan kegiatan sesuai aturan yang diberlakukan tidak dapat mengembangkan sesuai imajinasi sendiri.

Pada baseline 2 (A2) anak terlihat sangat senang untuk mengikuti kegiatan. Anak menjadi pribadi yang senang, ceria dan ramah untuk dapat membangun berinteraksi dengan lingkungannya. Orang tua menyadari bahwa anak mengalami banyak perubahan dari keterampilan sosial. Anak nyaman dengan kondisi di area umum, anak tidak marah saat mendengar kebisingan dan hiruk pikuk di area umum seperti area transportasi umum yang sering digunakan anak setiap kali akan menuju tempat terapi. Anak mau menunggu giliran untuk masuk kedalam kereta dan keluar dari kereta. Saat di rumah pun anak memiliki keteraturan sendiri saat bermain, tanpa diberikan instruksi anak mau merapikan mainan yang telah selesai dimainkan.

Peneliti dan terapis menemukan minat anak terhadap permainan dalam SRP, sehingga terapis akan menjadikan jenis permainan tersebut sebagai kegiatan utama untuk mengolah keterampilan bahasa dan sosial anak. Jenis permainan tersebut antara lain kegiatan memasak Pizza, permainan Putri Raja, bermain Bowling, bermain dokter-dokteran, membaca buku sambil bernyanyi. Kegiatan tersebut akan disiapkan dan ditempatkan ditempat terdepan di ruang belajar, agar anak mudah menjangkau permainan tersebut. Dan menyiapkan alternatif kegiatan lain yang sesuai dengan motivasi anak saat anak merasa membutuhkan permainan baru untuk dimainkan.

Peneliti juga melakukan perencanaan kegiatan SRP bersama terapis berdasarkan hasil evaluasi pada intervensi sesi pertama. Peneliti dan terapis telah memahami motivasi anak dalam kegiatan SRP yaitu kegiatan bernyanyi, bermain pura-pura yang dilakukan dengan semangat dan sangat tertarik dengan suara-suara khas dan mimik wajah yang sangat ekspresif. Pada siklus kedua, peneliti mengarahkan terapis untuk menyiapkan perencanaan kegiatan dengan Teknik melakukan kegiatan bermain dengan semangat dan memilih interaksi dengan anak menggunakan ekspresi wajah dan suara yang khas, beberapa kegiatan bermain dilakukan melalui bernyanyi untuk membangun interaksi komunikasi dengan anak.

Hasil intervensi sesi 2 (B2) nampak peningkatan yang sangat baik dalam keterampilan mempertahankan rentang atensi dan interaksi, kontak mata dan komunikasi non-verbal, keluwesan dalam melakukan kegiatan, serta verbal komunikasi. Anak terlihat sangat interaktif dalam membangun hubungan dengan orang lain, meskipun terkadang masih diarahkan untuk memulai. Hanya saja anak pasti melakukan interaksi dengan lingkungan saat anak merasa membutuhkan sesuatu. Anak lebih ekspresif untuk mengungkapkan apa yang diinginkan dan apa yang tidak disukainya. Kesadaran anak terhadap lingkungan cukup baik, anak memahami apa yang salah yang terjadi dilingkungannya dan anak mampu merespon nya dengan tepat. Seperti saat anak sadar bahwa adik laki-laki nya digendong oleh salah seorang terapis lain, saat ibu sedang merapikan perlengkapan yang akan dibawa pulang. Setiba nya anak diluar ruang langsung menghampiri terapis tersebut dan berkata "jangan", "kasih ibu ya" dan berulang ulang dikatakan hingga terapis memberikan adiknya kepada ibu.

Anak juga sudah memahami dan mengekspresikan emosinya secara tepat dan wajar. Anak mampu memberikan respon yang tepat saat terapis menangis atau terluka. Anak akan mendekati dan memeluk. Pada area fleksibilitas yang terlihat perubahannya tidak cukup signifikan seperti perkembangan pada area lainnya. Dari awal anak terlihat sangat rigid tentang satu aturan, pembiasaan mau pun hal-hal lainnya yang sangat detail seperti waktu, posisi benda. Dengan anak mau mengikuti arahan kegiatan dan cara bermain yang baru merupakan hal luar biasa yang ditunjukan oleh anak. Anak mau merubah rutinitas dan kebiasaannya bermain dengan mengikuti cara bermain baru yang diberikan oleh terapis. Anak juga lebih fleksibel saat orang lain yang menyalakan lampu saat senja tiba. Anak juga 
tidak terlalu perduli jika ada posisi sepatu yang tidak sesuai urutan, anak merasa nyaman sejauh sepatu diletakan ditempatnya, semua dikembalikan pada tempatnya dan tidak perduli dengan urutan dan lainnya.

Bagan pada gambar 5 dan 6 terlihat evaluasi kegiatan yang menggambarkan kondisi awal anak dan kondisi anak setelah mengikuti SRP selama 20 pertemuan kemampuan Bahasa dan komunikasi sosial meningkat. Peningkatan terlihat pada bagan perbandingan hasil A1B1-A2-B2 di setiap indikator penilaian bergerak keatas seiring meningkatnya keterampilan tersebut. Anak terlihat memiliki inisiatif untuk melakukan interaksi dengan orang lain disekitarnya, anak juga aktif dan partisipatif mengikuti kegiatan bermain yang diarahkan oleh terapis. Anak juga aktif untuk melakukan komunikasi dua arah dengan terapis, anak mampu berbicara sesuai kebutuhannya saat itu. Anak tampil menjadi anak yang bahagia dan ceria, mampu mengontrol emosinya dan anak mampu mengungkapkan emosi dengan cara yang tepat.

Meskipun kegiatan dilakukan dengan cara bermain, anak tetap memahami aturan dalam kegiatan, anak mampu menunggu giliran dan melakukan setiap arahan terapis dengan mandiri dan tuntas. Anak terlihat memiliki minat terhadap kegiatan bermain, dan memiliki pola bermain yang lebih beragam dengan mengurangi rigiditas yang ada. Anak memiliki keleluasaan untuk memilih kegiatan yang diminatinya, tanpa larangan, anak hanya diberikan Batasan kegiatan mana yang boleh ataupun yang sudah melewati Batasan yang diberikan yaitu permainan akan diberhentikan jika anak menyakiti diri sendiri, orang lain dan bendabenda disekitarnya.

Peneliti mengamati dan mengevaluasi kegiatan SRP yang telah dilaksanakan dalam 2 siklus bahwa terdapat kelemahan atau keterbatasan dalam pelaksanaan penelitian melalui kegiatan SRP yaitu konsistensi penggunaan bahasa sebagai pengantar kegiatan SRP pada anak yang belum konsisten. Anak terkadang lebih mengenal benda dalam Bahasa Inggris, tetapi orang tua tidak mempergunakan bahasa tersebut tidak konsisten di rumah. Sehingga bingung dalam merespon komunikasi dalam interaksi mungkin saja terjadi dan kemampuan untuk melakukan interaksi komunikasi juga menjadi terhambat, anak kesulitan memilih kata yang sesuai dalam Bahasa Inggris atau Bahasa Indonesia. Hal lainnya adalah konsistensi keterlibatan orang tua di rumah dalam melanjutkan pendampingan dengan prinsip SRP masih belum optimal.

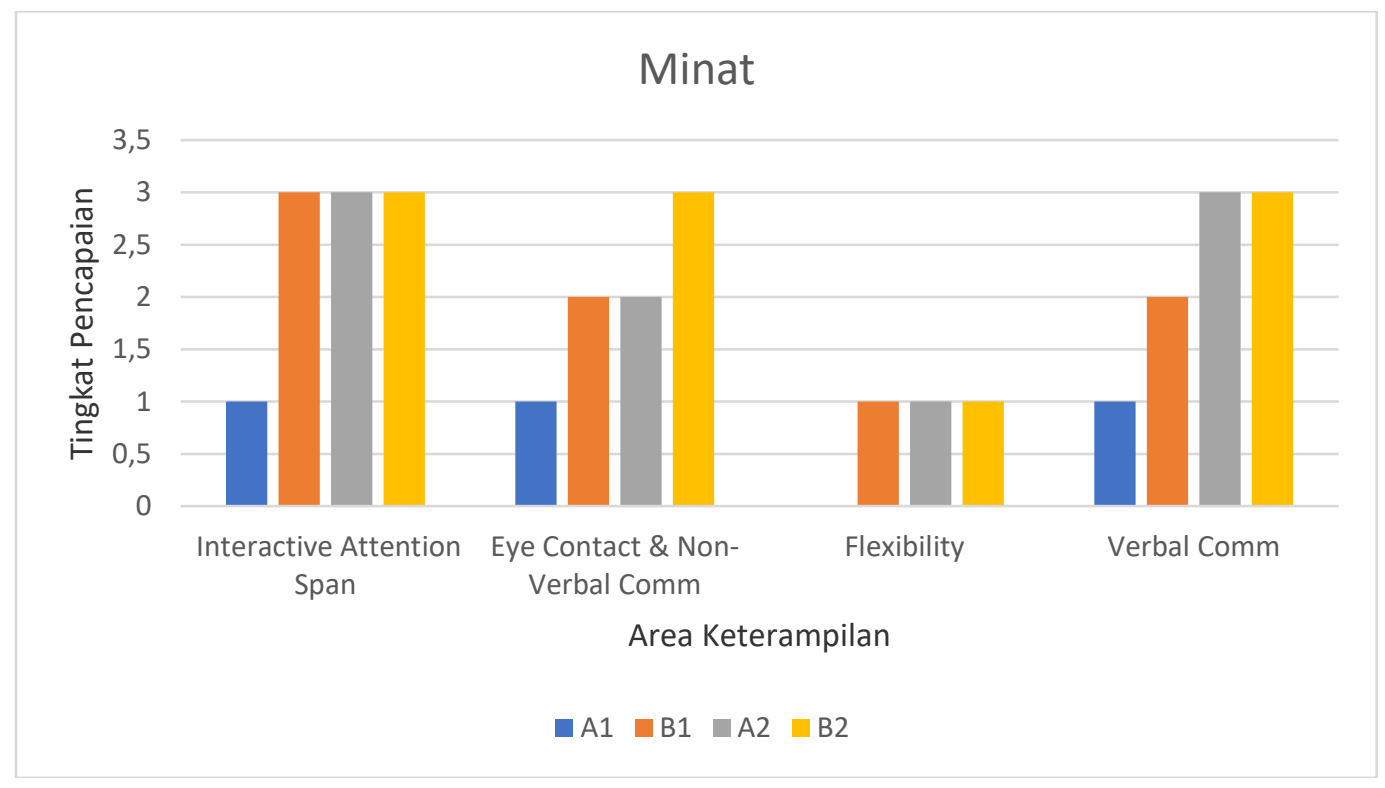

Gambar 6. Bagan Perbandingan Tingkat Pencapaian Minat (A1), (B1), (A2), (B2) 


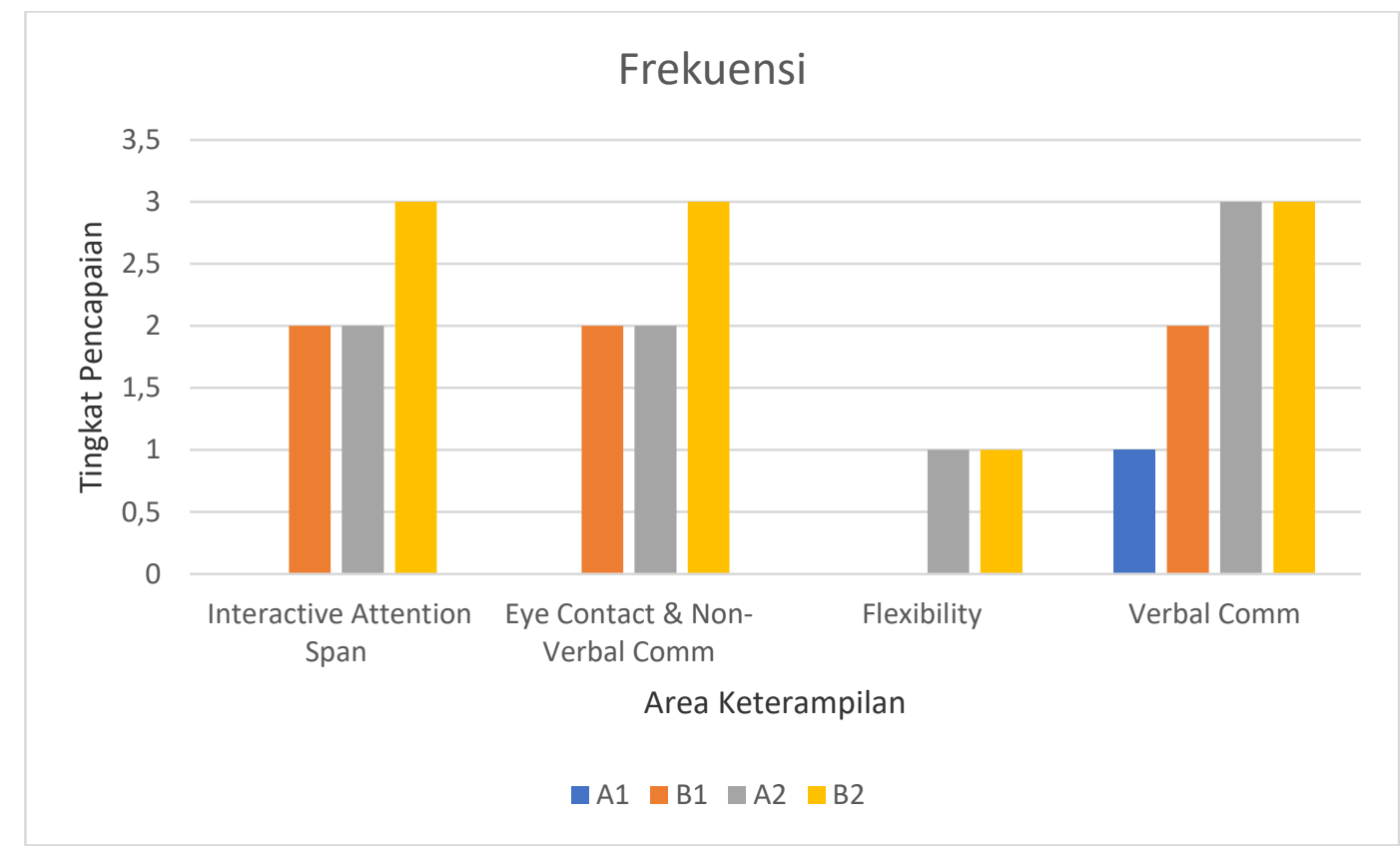

Gambar 6. Bagan Perbandingan Tingkat Pencapaian Frekuensi (A1), (B1), (A2), (B2)

\section{SIMPULAN}

Keterampilan bahasa dan sosial komunikasi pada anak autis sebagai subjek tunggal penelitian dapat berkembang melalui intervensi Son-Rise program yang dilakukan secara berkelanjutan dan terus menerus. Anak tampak anak memiliki kesadaran lingkungan lebih baik, memiliki inisiatif membangun interaksi dengan lingkungan, lebih aktif dan partisipatif dalam pembelajaran serta menunjukkan keceriaan dalam setiap kegiatan. Diperlukan dukungan orang tua untuk melakukan pendampingan lanjutan di rumah secara konsisten untuk perkembangan yang lebih optimal.

\section{UCAPAN TERIMA KASIH}

Terima kasih untuk para pembimbing yang telah membantu penyusunan penelitian ini hingga selesai. Terima kasih untuk Drisana Center yang telah bersedia menjadi tempat penelitian, terapis sebagai kolaborator, anak sebagai subjek penelitian dan orang tua dan responden penelitian yang telah mendukung penelitian ini hingga selesai.

\section{DAFTAR PUSTAKA}

Arikunto, S. (2003). Prosedur Penelitian Suatu Pendekatan Praktik. Rineka Cipta.

Astana, A. C., Syafrina, R., \& Karnadi, K. (2020). Pengaruh Pretend Play dan Jenis Kelamin terhadap Kemampuan Berpikir Divergen Anak Usia 5-6 Tahun. In Jurnal Obsesi : Jurnal Pendidikan Anak Usia Dini (Vol. 4, Issue 2). https://doi.org/10.31004/obsesi.v4i2.417

Bharatharaj, J., Huang, L., Krägeloh, C., Elara, M. R., \& Al-Jumaily, A. (2018). Social engagement of children with autism spectrum disorder in interaction with a parrot-inspired therapeutic robot. In Procedia Computer Science (Vol. 133). Elsevier B.V. https://doi.org/10.1016/j.procs.2018.07.045

Charman, T. (2010). Developmental approaches to understanding and treating autism. Folia Phoniatrica et Logopaedica, 62(4), 166-177. https://doi.org/10.1159/000314032

Chenausky, K., Brignell, A., Morgan, A., \& Tager-Flusberg, H. (2019). Motor speech impairment predicts expressive language in minimally verbal, but not low verbal, individuals with autism spectrum disorder. In Autism \& Developmental Language Impairments (Vol. 4). https://doi.org/10.1177/2396941519856333

Choque Olsson, N., Flygare, O., Coco, C., Görling, A., Råde, A., Chen, Q., Lindstedt, K., Berggren, S., Serlachius, E., Jonsson, U., Tammimies, K., Kjellin, L., \& Bölte, S. (2017). Social Skills 
Training for Children and Adolescents With Autism Spectrum Disorder: A Randomized Controlled Trial. In Journal of the American Academy of Child and Adolescent Psychiatry (Vol. 56, Issue 7). https://doi.org/10.1016/j.jaac.2017.05.001

Delehanty, A. D., Stronach, S., Guthrie, W., Slate, E., \& Wetherby, A. M. (2018). Verbal and nonverbal outcomes of toddlers with and without autism spectrum disorder, language delay, and global developmental delay. In Autism \& Developmental Language Impairments (Vol. 3). https://doi.org/10.1177/2396941518764764

Dockrell, J. E., Ricketts, J., Palikara, O., Charman, T., \& Lindsay, G. A. (2019). What Drives Educational Support for Children with Developmental Language Disorder or Autism Spectrum Disorder: Needs, or Diagnostic Category? In Frontiers in Education (Vol. 4, Issue April). https://doi.org/10.3389/feduc.2019.00029

Endang Supartini. (2009). Program Son-Rise untuk pengembangan bahasa anak autis. Pendidikan Khusus, 5.

Faisal, S. (1982). Metodelogi Penelitian Pendidikan. Usaha Nasional Surabaya.

fernanda dreux M. Fernandes. (2016). International Conference on Autism. Follow up of Language Theraphy with Children with ASD : Communication Activities Conducted at Home.

Fernandes, D.-N. (2013). Availability of Speech-Language Therapy to Individuals with ASD. In Autism-Open Access (Vol. 03, Issue 03). https:/ / doi.org/10.4172/2165-7890.1000117

Flippin, M. (2019). Father communication coaching for children with autism spectrum disorder: A single-subject study. In Autism and Developmental Language Impairments (Vol. 4). https:// doi.org/10.1177/2396941519877375

Fransisca, R., Wulan, S., \& Supena, A. (2020). Meningkatkan Percaya Diri Anak dengan Permainan Ular Tangga Edukasi. In Jurnal Obsesi : Jurnal Pendidikan Anak Usia Dini (Vol. 4, Issue 2). https://doi.org/10.31004/obsesi.v4i2.405

Greenspan, S. I. S. wieder. (2006). The Child with Special Needs.

Hasan, R. O. (2016). Meningkatkan Kemampuan Mengenal Huruf Hijaiyah Melalui Media Papan Magnetik Pada Anak Tunagrahita Sedang Kelas VI Slb Karya Padang. In E-JUPEKhu (JURNAL ILMIAH PENDIDIKAN KHUSUS) (Vol. 5, Issue 2).

Hogan, W., \& Hogan, B. K. (2007). The Son-Rise Program: Developmental Model.

Houghton, K., Schuchard, J., Lewis, C., \& Thompson, C. K. (2013). Promoting child-initiated socialcommunication in children with autism: Son-Rise Program intervention effects. In Journal of Communication Disorders (Vol. 46, Issues 5-6). Elsevier Inc. https://doi.org/10.1016/j.jcomdis.2013.09.004

Hurlock, E. B. (1978). Child Development, Perkembangan Anak (sixth). Erlangga.

Isbel, C. (2005). The Inclusive Learning Center Book.

Jansen, R., Maljaars, J., Verhappen, A., Zink, I., Steyaert, J., \& Noens, I. (2020). Problem behavior in young children referred with language difficulties: Relations to language and intentional communication. Autism and Developmental Language Impairments, 5. https://doi.org/10.1177/2396941519900076

John W, S. (2002). Life-Span Development, Perkembangan Masa hidup (1st ed.). Erlangga.

Kaale, A., Fagerland, M. W., Martinsen, E. W., \& Smith, L. (2014). Preschool-based social communication treatment for children with autism: 12-month follow-up of a randomized trial. In Journal of the American Academy of Child and Adolescent Psychiatry (Vol. 53, Issue 2). Elsevier Inc. https:/ / doi.org/10.1016/j.jaac.2013.09.019

Kaufman, B. N. (1993). SonRise The Miracle Continues.

Khantreejitranon, A. (2018). Using a social story intervention to decrease inappropriate behavior of preschool children with autism. In Kasetsart Journal of Social Sciences (Vol. 39, Issue 1). Elsevier Ltd. https://doi.org/10.1016/j.kjss.2017.12.019

Killmeyer, S., \& Kaczmarek, L. (2017). Parent training and joint engagement in young children with autism spectrum disorder. In Autism \& Developmental Language Impairments (Vol. 2). https:// doi.org/10.1177/2396941517699214

Lane, J. D., Shepley, C., Sartini, E., \& Hogue, A. (2020). Modifying a naturalistic language intervention for use in an elementary school classroom. In Autism and Developmental Language Impairments (Vol. 5). https:// doi.org/10.1177/2396941519896925 
Lavi, A., \& J. Mainess, K. (2019). A Comparative Analysis of Social (Pragmatic) Communication Skills in Students with High-Functioning Autism and Pragmatic Language Impairment Using Video-Based Assessments. In Autism-Open Access (Vol. 09, Issue 02). https://doi.org/10.35248/2165-7890.19.9.239

Lobban-Shymko, J., Im-Bolter, N., \& Freeman, N. (2017). Early social communicative skills as predictors of symptom severity in autism spectrum disorder. In Autism \& Developmental Language Impairments (Vol. 2). https:// doi.org/10.1177/2396941517743418

Loukusa, S., Mäkinen, L., Kuusikko-Gauffin, S., Ebeling, H., \& Leinonen, E. (2018). Assessing social-pragmatic inferencing skills in children with autism spectrum disorder. In Journal of Communication Disorders (Vol. 73, Issue January 2017). https://doi.org/10.1016/j.jcomdis.2018.01.006

Mody, M., \& Belliveau, J. W. (2012). Speech and Language Impairments in Autism: Insights from Behavior and Neuroimaging. In American Chinese Journal of Medicine and Science (Vol. 5, Issue 3). https:// doi.org/10.7156/v5i3p157

Mohammad, H., \& Abu-Amara, F. (2019). A mobile social and communication tool for autism. In International Journal of Emerging Technologies in Learning (Vol. 14, Issue 19). https://doi.org/10.3991/ijet.v14i19.10887

Monks, F. . (1992). Psikologi Perkembangan (S. R. (ed.)). Gajah Mada University Press.

Natalia, N. (2016). 2 nd International Conference on Autism, The efficacyof a 12-week exercise intervention in 11-16 yearold adolescents with autism spectrum disorder. Journal Psycology, 2, 78.

Natalia, N. (2020). International Conference on International conference on (RDHR-2020). In International Conference on International conference on (RDHR-2020) (Vol. 6, Issue 4). https://doi.org/10.22161/conf.rdhr.2020

Paulraj, S. J. P. V., Alwi, N. A. B., \& Vetrayan, J. (2016). Emotional Behaviour among Autism and Typically Developing Children in Malaysia. In Procedia - Social and Behavioral Sciences (Vol. 222). https://doi.org/10.1016/j.sbspro.2016.05.169

Purwanto, N. (2006). Prinsip-Prinsip dan Teknik Evaluasi Pengajaran. Pt. Remaja Rosdakarya.

Siti Nurhasanah, D. W. U. (2004). Statistika Bisnis. UMM Press.

Sugiyono. (2016). Metode Penelitian Managemen (5th ed.). Alfabeta.

Sunanto, J., Takeuchi, K., \& Nakata, H. (2005). Pengantar Penelitian Dengan Subyek Tunggal. CRICED University of Tsukuba, 1-150.

Thompson, C. K., \& Jenkins, T. (2016). Training Parents to Promote Communication and Social Behavior in Children with Autism: The Son-Rise Program. In Journal of Communication Disorders, Deaf Studies \& Hearing Aids (Vol. 04, Issue 01). https:// doi.org/10.4172/2375$\underline{4427.1000147}$

Tony Charman. (n.d.). Developmental Approaches to Understanding and Treating Autism. Developmental Approaches to Understanding and Treating Autism, 166, 170, 172, 174.

Weismer, S. E. (n.d.). Developmental Language Disorder: Challenges and Implications of CrossGroup Comparisons. In Department of Communication Sciences and Disorders/Waisman Center, University of Wisconsin-Madison, Madison, Wisc., USA.

Williams, K. (2001). The Son-Rise Program Intervention for Autism: An Investigation into Prerequisites for Evaluation and Family Experiences. The University of Edinburgh.

Wishart, K. R. W. \& J. G. (2003). The Son-Rise Program Intervention for Autism: An Intervention into Family Experiences. Intellectual Disability Research, 47, 291-299. https://doi.org/10.1046/j.1365-2788.2003.00491.x

Woodard, C. R., Chung, J., \& Korn, M. (2014). A pilot study of the meta-play method: a novel play intervention for toddlers with autism. In Journal of Autism (Vol. 1, Issue 1). https://doi.org/10.7243/2054-992X-1-3

Yuniati, S., \& Rohmadheny, P. S. (2020). Bermain Peran: Sebuah Metode untuk Meningkatkan Kemampuan Bahasa Ekspresif Anak. In Jurnal Obsesi : Jurnal Pendidikan Anak Usia Dini (Vol. 5, Issue 1). https:// doi.org/10.31004/obsesi.v5i1.509 


\section{Lampiran 1}

\section{Tabel 1. Program Son-Rise}

The Four Fundamentals of Socialization

1. Eye Contact \& Non- Verbal Communication

2. Verbal Communication

3. Interactive Attention Span

4. Flexibility

\begin{tabular}{|c|c|c|c|c|c|}
\hline \multicolumn{6}{|c|}{ Eye Contact \& Non- Verbal Communication } \\
\hline & Stage 1 & Stage 2 & Stage 3 & Stage 4 & Stage 5 \\
\hline $\begin{array}{l}\text { Function } \\
\text { of Eye } \\
\text { Contact }\end{array}$ & $\begin{array}{l}\text { Looks at } \\
\text { others to } \\
\text { start/ } \\
\text { continue an } \\
\text { interaction }\end{array}$ & $\begin{array}{c}\text { Makes eye } \\
\text { contact to get } \\
\text { need met }\end{array}$ & $\begin{array}{c}\text { Uses eye } \\
\text { contact to } \\
\text { draw attention } \\
\text { to } \\
\text { object/events } \\
\text { or interest }\end{array}$ & $\begin{array}{l}\text { Looks to } \\
\text { maintain } \\
\text { others } \\
\text { attention }\end{array}$ & $\begin{array}{c}\text { Looks to } \\
\text { evaluate others } \\
\text { social cues }\end{array}$ \\
\hline Frequency & $\begin{array}{l}\text { Looks with } \\
\text { occational } \\
\text { flickers of } \\
\text { expression }\end{array}$ & $\begin{array}{c}\text { Smile or } \\
\text { laughs while } \\
\text { in an } \\
\text { interaction }\end{array}$ & $\begin{array}{l}\text { Copies some } \\
\text { simple } \\
\text { exaggerated } \\
\text { facial } \\
\text { movements }\end{array}$ & $\begin{array}{l}\text { Spontaneously } \\
\text { demonstrates a } \\
\text { range of facial } \\
\text { expression }\end{array}$ & $\begin{array}{l}\text { Responds } \\
\text { approriately to } \\
\text { others facial } \\
\text { expressions }\end{array}$ \\
\hline $\begin{array}{l}\text { Type of } \\
\text { Activity }\end{array}$ & $\begin{array}{l}\text { Physically } \\
\text { moves others } \\
\text { to get what } \\
\text { he/she wants }\end{array}$ & $\begin{array}{l}\text { Simple } \\
\text { gestures upon } \\
\text { request }\end{array}$ & $\begin{array}{l}\text { Spontaneous } \\
\text { simple } \\
\text { gestures }\end{array}$ & $\begin{array}{c}\text { Uses } \\
\text { spontaneous } \\
\text { gestures to } \\
\text { enhance verbal } \\
\text { communication }\end{array}$ & $\begin{array}{c}\text { Understands, } \\
\text { responds to and } \\
\text { uses basic social } \\
\text { cues }\end{array}$ \\
\hline
\end{tabular}

\begin{tabular}{|c|c|c|c|c|c|}
\hline \multicolumn{6}{|c|}{ Verbal Communication } \\
\hline & Stage 1 & Stage 2 & Stage 3 & Stage 4 & Stage 5 \\
\hline $\begin{array}{l}\text { Vocabulary/ } \\
\text { Content }\end{array}$ & $\begin{array}{l}\text { Speech-Like } \\
\text { sounds to } 50 \\
\text { single words }\end{array}$ & $\begin{array}{c}\text { Simple } \\
\text { Phrases (2-3 } \\
\text { words } \\
\text { combinations) }\end{array}$ & $\begin{array}{c}\text { Simple } \\
\text { Sentences } \\
\text { (noun + verb) }\end{array}$ & $\begin{array}{c}\text { Complex } \\
\text { Sentences } \\
\text { (grammaticall } \\
\text { y correct) }\end{array}$ & $\begin{array}{l}\text { Combined } \\
\text { Complex } \\
\text { Sentences }\end{array}$ \\
\hline $\begin{array}{l}\text { Parts of } \\
\text { Speech }\end{array}$ & Nouns, Verb & $\begin{array}{l}\text { Adjectives, } \\
\text { Prepositions }\end{array}$ & $\begin{array}{c}\text { Articles, } \\
\text { Conjucntions }\end{array}$ & Pronouns & $\begin{array}{c}\text { Fluent use of } \\
\text { all parts of } \\
\text { speech }\end{array}$ \\
\hline Clarity & Partially Clear & $\begin{array}{c}\text { Generally } \\
\text { clear }\end{array}$ & & Consistently & \\
\hline $\begin{array}{l}\text { Concersation } \\
\text { Loops }\end{array}$ & $\mathrm{N} / \mathrm{A}$ & 1 loop & 2 loops & 3-5 loops & $\begin{array}{c}6 \text { loops or } \\
\text { more }\end{array}$ \\
\hline \multirow{3}{*}{$\begin{array}{c}\text { Conversation } \\
\text { Content }\end{array}$} & \multirow{3}{*}{$\begin{array}{l}\text { Prompted } \\
\text { (Request by } \\
\text { other) }\end{array}$} & \multirow{3}{*}{$\begin{array}{c}\text { Spontaneousl } \\
\text { y } \\
\text { (unprompted) } \\
\text { Communicate } \\
\text { wants/not } \\
\text { wants }\end{array}$} & $\begin{array}{l}\text { Makes simple } \\
\text { comments }\end{array}$ & $\begin{array}{c}\text { Makes } \\
\text { complex } \\
\text { statements }\end{array}$ & \multirow{3}{*}{$\begin{array}{l}\text { Makes } \\
\text { reflective } \\
\text { comments } \\
\text { and asks } \\
\text { relevant } \\
\text { reflective } \\
\text { questions }\end{array}$} \\
\hline & & & $\begin{array}{c}\text { Asks/ answes } \\
\text { simple } \\
\text { question }\end{array}$ & \multirow{2}{*}{$\begin{array}{c}\text { Asks/ answers } \\
\text { complex } \\
\text { questions }\end{array}$} & \\
\hline & & & $\begin{array}{l}\text { Spontaneousl } \\
\text { y construct } \\
\text { original } \\
\text { sentences }\end{array}$ & & \\
\hline $\begin{array}{l}\text { Function of } \\
\text { Verbal } \\
\text { Comm. }\end{array}$ & $\begin{array}{l}\text { To get needs } \\
\text { met }\end{array}$ & $\begin{array}{l}\text { To start/ } \\
\text { continue an } \\
\text { interaction }\end{array}$ & $\begin{array}{c}\text { To create a } \\
\text { shared } \\
\text { experience }\end{array}$ & $\begin{array}{c}\text { To share } \\
\text { coherent story } \\
\text { (Relevant to } \\
\text { the } \\
\text { conversation) }\end{array}$ & $\begin{array}{l}\text { To seek others } \\
\text { internal } \\
\text { experiences } \\
\text { (emotion \& } \\
\text { thoughts) }\end{array}$ \\
\hline
\end{tabular}


DOI: 10.31004 /obsesi.v6i4.963

\begin{tabular}{|c|c|c|c|c|c|}
\hline \multicolumn{6}{|c|}{ Verbal Communication } \\
\hline & Stage 1 & Stage 2 & Stage 3 & Stage 4 & Stage 5 \\
\hline & & & & $\begin{array}{l}\text { To seek others } \\
\text { Personal } \\
\text { Information } \\
\text { within a } \\
\text { conversation } \\
\end{array}$ & $\begin{array}{l}\text { To share } \\
\text { internal } \\
\text { experience } \\
\text { (emotion \& } \\
\text { thoughts) } \\
\end{array}$ \\
\hline \multicolumn{6}{|c|}{ Interactive Attention Span (Interaction = inclusion of another person in a game or activity) } \\
\hline & Stage 1 & Stage 2 & Stage 3 & Stage 4 & Stage 5 \\
\hline Duration & $\frac{\text { Up to2 }}{\underline{\text { minutes }}}$ & $\begin{array}{c}\text { 3-4 minutes or } \\
\text { more }\end{array}$ & 5-9 minutes & 10-20 minutes & $\begin{array}{c}\text { Ages } \\
\text { appropriate } \\
\text { (typically 3-5 } \\
\text { minutes per } \\
\text { year of a child } \\
\text { age) }\end{array}$ \\
\hline Frequency & $\begin{array}{l}\text { Up to } 3 x / \\
\text { hour }\end{array}$ & $4 \times /$ hour & $\begin{array}{l}5 x / \text { hour or } \\
\text { more }\end{array}$ & $\begin{array}{c}\text { Up to } 5 x / \\
\text { hour } \\
\text { (Duration } \\
\text { must be } 10 \\
\text { min. or more) }\end{array}$ & $\begin{array}{l}\text { Continuously } \\
\text { interactive }\end{array}$ \\
\hline $\begin{array}{l}\text { Type of } \\
\text { Activity }\end{array}$ & $\begin{array}{c}\text { Interacts } \\
\text { within shared } \\
\text { physical } \\
\text { activities }\end{array}$ & $\begin{array}{c}\text { Interacts around } \\
\text { simple shared } \\
\text { objects/activitie } \\
\text { s }\end{array}$ & $\begin{array}{c}\text { Interacts } \\
\text { within } \\
\text { symbolic } \\
\text { imaginative } \\
\text { play }\end{array}$ & $\begin{array}{l}\text { Interacts } \\
\text { within } \\
\text { imaginative } \\
\text { role-play } \\
\text { activities }\end{array}$ & $\begin{array}{l}\text { Interacts } \\
\text { within a } \\
\text { variety of } \\
\text { activities }\end{array}$ \\
\hline $\begin{array}{l}\text { Peer } \\
\text { Friendship } \\
\mathrm{s}\end{array}$ & $\begin{array}{l}\text { (Fleeting or no } \\
\text { interest in } \\
\text { peers) }\end{array}$ & $\begin{array}{l}\text { (Plays beside } \\
\text { peers showing } \\
\text { interest without } \\
\text { interacting with } \\
\text { them) }\end{array}$ & $\begin{array}{c}\text { Simple } \\
\text { interactions } \\
\text { with peers }\end{array}$ & $\begin{array}{c}\text { Interacts } \\
\text { appropriately } \\
\text { with a peer }\end{array}$ & $\begin{array}{c}\text { Appropriatel } \\
\text { y interacts } \\
\text { with small } \\
\text { groups of } \\
\text { peers } \\
\end{array}$ \\
\hline \multicolumn{6}{|l|}{ Flexibility } \\
\hline & Stage 1 & Stage 2 & Stage 3 & Stage 4 & Stage 5 \\
\hline \multirow[b]{2}{*}{ Flexibility } & \multirow[b]{2}{*}{$\begin{array}{l}\text { Allows you to } \\
\text { assist within } \\
\text { his/ her } \\
\text { repetitious } \\
\text { interactions }\end{array}$} & $\begin{array}{c}\text { Allows } \\
\text { peripheral } \\
\text { variations to } \\
\text { his/her } \\
\text { repetitious } \\
\text { interactions }\end{array}$ & $\begin{array}{l}\text { Allows central } \\
\text { variations to } \\
\text { his/her } \\
\text { repetitious } \\
\text { interactions }\end{array}$ & $\begin{array}{l}\text { Flexible within } \\
\text { his/her area of } \\
\text { interset }\end{array}$ & $\begin{array}{c}\text { Flexible within } \\
\text { a variety of } \\
\text { activities }\end{array}$ \\
\hline & & $\begin{array}{l}\text { Physically } \\
\text { participates in } \\
\text { the interaction } \\
\text { Verbally } \\
\text { participates in } \\
\text { the interaction }\end{array}$ & $\begin{array}{l}\text { Shows an } \\
\text { interest in } \\
\text { anothers } \\
\text { activity }\end{array}$ & $\begin{array}{c}\text { Allows } \\
\text { variations } \\
\text { within anothers } \\
\text { activity } \\
\text { Share } \\
\text { interactive time } \\
\text { between } \\
\text { his/her activity } \\
\text { and anothers } \\
\text { activity }\end{array}$ & $\begin{array}{c}\text { Spontaneous } \\
\text { within a } \\
\text { variety of } \\
\text { activities }\end{array}$ \\
\hline $\begin{array}{l}\text { Peer } \\
\text { Friendships }\end{array}$ & $\begin{array}{l}\text { Settles easily } \\
\text { within a } \\
\text { highly } \\
\text { supportive } \\
\text { environment }\end{array}$ & $\begin{array}{l}\text { Calmly and } \\
\text { easily handles } \\
\text { limits and } \\
\text { boundaries } \\
\text { within a } \\
\text { highly } \\
\end{array}$ & $\begin{array}{c}\text { Interact easily } \\
\text { in a } \\
\text { moderately } \\
\text { supportive } \\
\text { environment }\end{array}$ & $\begin{array}{c}\text { Manages } \\
\text { sensory input } \\
\text { and change in } \\
\text { typical ages } \\
\text { appropriate }\end{array}$ & $\begin{array}{c}\text { Calmly and } \\
\text { easily } \\
\text { manages most } \\
\text { transitions and } \\
\text { unstructured } \\
\text { situations }\end{array}$ \\
\hline
\end{tabular}


Efektifitas Son-Rise Program dalam Meningkatkan Keterampilan Bahasa, Sosial Komunikasi pada Anak Autis DOI: 10.31004/obsesi.v6i4.963

\begin{tabular}{|c|c|c|c|c|c|c|c|}
\hline \multicolumn{8}{|l|}{ Flexibility } \\
\hline & \multicolumn{2}{|c|}{ Stage 1} & Stage 2 & Stage 3 & \multicolumn{2}{|c|}{ Stage 4} & Stage 5 \\
\hline & & & $\begin{array}{c}\text { supportive } \\
\text { environment }\end{array}$ & & \multicolumn{2}{|c|}{$\begin{array}{l}\text { environments, } \\
\text { with help }\end{array}$} & \\
\hline \multicolumn{8}{|c|}{$\begin{array}{l}\text { The Craying/ Tantruming/ Whining chart below does not follow Stage 1-5. Instead, use the chart to } \\
\text { track your child's crying/ tantruming/ whining communication to focus on helping him/ her } \\
\text { communicate verbally }\end{array}$} \\
\hline \multicolumn{8}{|c|}{ Craying/ Tantruming/Whining Communication } \\
\hline Frequency & $\begin{array}{c}\text { More } \\
\text { than } \\
4 \mathrm{x} / \\
\mathrm{hr}\end{array}$ & $\frac{1-4 x /}{\underline{h r}}$ & $\begin{array}{c}\text { Less than } 1 \mathrm{x} / \\
\mathrm{hr}\end{array}$ & $3-4 x /$ day & Less thar & $3 x /$ day & \multirow{3}{*}{$\begin{array}{l}\text { Communicates } \\
\text { using } \\
\text { language }\end{array}$} \\
\hline Duration & $\begin{array}{l}\text { More } \\
\text { than } \\
1 \mathrm{hr}\end{array}$ & $\begin{array}{c}30-60 \\
\min \end{array}$ & $10-30 \mathrm{~min}$ & $5-10 \mathrm{~min}$ & $1-5 \min$ & $\begin{array}{l}\text { Less } \\
\text { than } 1 \\
\min \end{array}$ & \\
\hline Quality & $\begin{array}{r}\text { Screa } \\
\text { shor } \\
\text { thro } \\
\text { object } \\
\text { ban } \\
\text { hitting } \\
\text { othe1 }\end{array}$ & $\begin{array}{l}\text { ning/ } \\
\text { ting, } \\
\text { wing } \\
\text { head- } \\
\text { ying, } \\
\text { self or } \\
\text { s, etc. }\end{array}$ & $\begin{array}{c}\text { Screaming/ } \\
\text { Shouting }\end{array}$ & Crying & $\begin{array}{l}\text { Crying/ } \\
\text { whining }\end{array}$ & Whining & \\
\hline
\end{tabular}




\section{Lampiran 2}

Tabel 3. Format Penilaian

THE SON-RISE PROGRAM EVALUATION

1. Exclusive and Repetitious Activities

\begin{tabular}{cc}
\hline Activity & Most Effective Way of Joining \\
\hline Possible Interests or Motivations: & \\
\hline
\end{tabular}

2. Eye Contact/ Non-Verbal Communication

a) Eye Contact/Expression Sharing Challenge/Circumstance Most Effective Technique Applied

Make eye contact to get needs met:

Looks at others with interest:

Smile or laughs while in an interaction:

b) Non-Verbal Communication

Type of Communication Used /

Circumstances

Simple gestures upon request:

Crying and whining:

\section{Communication}

Type of Language Used $\quad$ Circumstance

Speaks in simple phrases:

Clarity of speech is generally clear and

understandable:

Has conversations that consist of 1 loop or more:

Spontaneously communicates wants/ not wants:

\begin{tabular}{|c|c|c|c|}
\hline \multicolumn{4}{|c|}{ 4. Interactive Attention Span } \\
\hline Name of Activity & Goal & $\begin{array}{c}\text { Frequency } \\
\text { and } \\
\text { Duration }\end{array}$ & $\begin{array}{l}\text { Technique Applied to Lengthen } \\
\text { Interaction }\end{array}$ \\
\hline Average & & rage & Average \\
\hline Interaction & & action & Interaction \\
\hline Attention Span & Att & on Span & Attention Span \\
\hline
\end{tabular}

\section{Flexibility}

Challenge

Most Effective Technique Applied

Allows peripheral veriations to rigid/ repetitious interactions:

Physically participates in interactions:

Verbally participates in interactions:

Calmly/easily handles limits/ boundaries:

\section{Motivations}

7. Special Change and New Observations Highest Areas of Motivation

8. Questions/Topics for Discussion/Program Goals 


\section{Lampiran 3}

Tabel 5. Program SRP

\begin{tabular}{|c|c|}
\hline Nama & \\
\hline Periode & \\
\hline Tempat Tanggal Lahir & 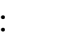 \\
\hline Terapis & : \\
\hline Nama Orang tua & \\
\hline Penanggung Jawab Prc & ram \\
\hline
\end{tabular}

\begin{tabular}{|c|c|c|c|c|}
\hline & \multicolumn{4}{|c|}{ Area } \\
\hline $\begin{array}{c}\text { Area } \\
\text { Pembelajaran }\end{array}$ & $\begin{array}{c}\text { Kontak mata \& } \\
\text { Komunikasi Non- } \\
\text { Verbal }\end{array}$ & $\begin{array}{l}\text { Komunikasi } \\
\text { Verbal }\end{array}$ & $\begin{array}{l}\text { Rentang } \\
\text { perhatian }\end{array}$ & Fleksibilitas \\
\hline Tujuan & $\begin{array}{l}\text { Mendorong Bulan } \\
\text { untuk melihat } \\
\text { dengan ekspresi } \\
\text { pada orang lain } \\
\text { seperti, } \\
\text { mengedipkan } \\
\text { mata, kaget } \\
\text { dengan membuka } \\
\text { mulut dan lainnya }\end{array}$ & $\begin{array}{l}\text { Meningkatkan } \\
\text { kata sehingga } \\
\text { Bulan memiliki } \\
\text { perbendaharaan } \\
\text { kata sekitar 6-50 } \\
\text { kata atau lebih }\end{array}$ & $\begin{array}{l}\text { Mendorong Bulan } \\
\text { untuk } \\
\text { memperpanjang } \\
\text { rentang atensi nya } \\
\text { sekitar 5-9 menit }\end{array}$ & $\begin{array}{l}\text { Membantu Bulan } \\
\text { untuk terlibat } \\
\text { dalam permainan } \\
\text { dengan peraturan } \\
\text { sederhana dan } \\
\text { terstruktur }\end{array}$ \\
\hline \multirow{3}{*}{$\begin{array}{c}\text { Teknik } \\
\text { Pembelajaran }\end{array}$} & $\begin{array}{l}\text { Memposisikan } \\
\text { level mata sejajar } \\
\text { atau dibawah } \\
\text { Bulan, } \\
\text { memudahkan } \\
\text { Bulan untuk } \\
\text { melihat kearah } \\
\text { terapis } \\
\end{array}$ & $\begin{array}{l}\text { Memposisikan } \\
\text { diri sebaik yang } \\
\text { bisa dilakukan } \\
\text { untuk } \\
\text { mendapatkan } \\
\text { kontak mata } \\
\text { dengan Bulan saat } \\
\text { berinteraksi }\end{array}$ & $\begin{array}{l}\text { Memberikan cara } \\
\text { yang mudah } \\
\text { untuk Bulan } \\
\text { berpartisipasi } \\
\text { dalam kegiatan }\end{array}$ & $\begin{array}{l}\text { Memuji Bulan } \\
\text { setiap ia } \\
\text { berpartisipasi } \\
\text { dalam kejadian } \\
\text { atau kegiatan } \\
\text { permainan }\end{array}$ \\
\hline & $\begin{array}{l}\text { Memberikan } \\
\text { perhatian pada } \\
\text { Bulan dengan } \\
\text { menerima apa } \\
\text { yang } \\
\text { dilakukannya }\end{array}$ & $\begin{array}{l}\text { Memberikan kata } \\
\text { yang bermakna di } \\
\text { setiap benda atau } \\
\text { mainan yang } \\
\text { sedang } \\
\text { dieksplorasi oleh } \\
\text { Bulan atau suara } \\
\text { bermakna yang } \\
\text { mewakili emosi } \\
\text { saat itu (misalnya } \\
\text { kaget, bahagia } \\
\text { atau senang, sedih } \\
\text { dan lainnya } \\
\text { dengan ekspresi } \\
\text { mimik wajah) }\end{array}$ & $\begin{array}{l}\text { Memberikan } \\
\text { sesuatu mainan } \\
\text { yang Bulan } \\
\text { senangi sebelum } \\
\text { meminta Bulan } \\
\text { melakukan apa } \\
\text { pun yang ingin } \\
\text { dia lakukan } \\
\text { (misalnya, jika } \\
\text { terapis memulai } \\
\text { satu permainan, } \\
\text { berikan Bulan } \\
\text { giliran untuk } \\
\text { melakukannya } \\
\text { untuk beberapa } \\
\text { waktu sebelum } \\
\text { mengarahkan nya } \\
\text { untuk berkata } \\
\text { "mau lagi” }\end{array}$ & $\begin{array}{l}\text { Terapis perlu } \\
\text { menjadi fleksibel } \\
\text { saat berinteraksi } \\
\text { dengan Bulan }\end{array}$ \\
\hline & $\begin{array}{l}\text { Memberikan } \\
\text { ekspresi mimik } \\
\text { wajah untuk } \\
\text { memberikan } \\
\text { makna terhadap } \\
\text { perasaan yang } \\
\text { dirasakan terapis, }\end{array}$ & $\begin{array}{l}\text { Berhenti } \\
\text { sementara untuk } \\
\text { mengatakan apa } \\
\text { pun dan } \\
\text { menunggu sampai } \\
\text { Bulan merespon } \\
\text { terapis sebelum }\end{array}$ & $\begin{array}{l}\text { Persisten, jika } \\
\text { Bulan sudah } \\
\text { mulai ingin } \\
\text { meninggalkan } \\
\text { terapis dan } \\
\text { kegiatannya, } \\
\text { memanggil dia }\end{array}$ & $\begin{array}{l}\text { Memberikan saran } \\
\text { permainan } \\
\text { terstruktur pada } \\
\text { Bulan }\end{array}$ \\
\hline
\end{tabular}




\begin{tabular}{|c|c|c|}
\hline $\begin{array}{l}\text { sehingga Bulan } \\
\text { mampu } \\
\text { mengidentifikasi } \\
\text { mimik wajah } \\
\text { tersebut sehingga } \\
\text { bermakna sesuai } \\
\text { situasi dan kondisi }\end{array}$ & $\begin{array}{l}\text { melanjutkan } \\
\text { bicara atau } \\
\text { berkata-kata lagi }\end{array}$ & $\begin{array}{l}\text { kembali dengan } \\
\text { cara yang sangat } \\
\text { playfull sampai dia } \\
\text { kembali tertarik } \\
\text { dan mau } \\
\text { melakukannya } \\
\text { lagi }\end{array}$ \\
\hline
\end{tabular}

saat itu.

\begin{tabular}{|c|c|c|c|}
\hline \multirow[t]{2}{*}{$\begin{array}{l}\text { Memberikan } \\
\text { penghargaan } \\
\text { dengan merespon } \\
\text { setiap kali Bulan } \\
\text { memberikan } \\
\text { mimik wajah yang } \\
\text { mewakili } \\
\text { perasaannya } \\
\text { kepada terapis }\end{array}$} & $\begin{array}{l}\text { Menggunakan } \\
\text { suara, wajah dan } \\
\text { gerakan yang } \\
\text { menarik ketika } \\
\text { berinteraksi } \\
\text { dengan Bulan } \\
\text { (bisa dengan } \\
\text { suara yang bukan } \\
\text { suara biasanya) }\end{array}$ & $\begin{array}{l}\text { Jika Bulan } \\
\text { menyebutkan } \\
\text { nama-nama } \\
\text { mainan yang } \\
\text { sedang } \\
\text { dipegangnya, } \\
\text { bergabung dan } \\
\text { membangun satu } \\
\text { kegiatan baru } \\
\text { yang lebih } \\
\text { bermakna } \\
\text { daripada hanya } \\
\text { sekedar } \\
\text { menyebutkan satu } \\
\text { persatu nama } \\
\text { benda yang dia } \\
\text { pegang }\end{array}$ & $\begin{array}{l}\text { Model permainan } \\
\text { terstruktur }\end{array}$ \\
\hline & $\begin{array}{l}\text { Selalu } \\
\text { mengarahkan } \\
\text { atensi dalam } \\
\text { setiap interaksi } \\
\text { kedalam kontak } \\
\text { mata }\end{array}$ & & \\
\hline
\end{tabular}

